\title{
Endonuclease activity of RecJ from extremely alkaliphilic Bacillus
}

\section{alcalophilus}

$$
\begin{gathered}
\text { Minggang Zheng }{ }^{1,3^{* \#}} \text {, Wen Wang }{ }^{1,3^{*}} \text {, Liya Ma }{ }^{1,3} \text {, Ling Wang }{ }^{1,3} \text {, Lingyun } \mathrm{Qu}^{1,3} \text {, } \\
\text { Xipeng Liu }{ }^{5} \text {, Hailiang Liu }{ }^{2,4 \#}
\end{gathered}
$$

${ }^{1}$ The First Institute of Oceanography, Ministry of Natural Resources, Qingdao 266061, China.

${ }^{2}$ Institute for Regenerative Medicine, Shanghai East Hospital, Tongji University School of Medicine, Shanghai, 200123, China.

${ }^{3}$ College of Chemistry and Chemical Engineering and Environment, Qingdao University, 308 NingXia Road, Qingdao 266071, China.

${ }^{4}$ College of Life Sciences, Key Laboratary of Xinjiang Phytomedicine Resource and Utilization of Ministry of Education, Shihezi University, Shihezi, Xinjiang 832003, China.

${ }^{5}$ State Key Laboratory of Microbial Metabolism, School of Life Sciences and Biotechnology, Shanghai Jiao Tong University, 800 Dongchuan Road, Shanghai 200240, China.

* These authors made equal contributions to this manuscript.

\section{\# Corresponding authors:}

Ming-Gang Zheng, Ph.D.

E-mail: zmg@fio.org.cn

And Hailiang Liu, Ph.D.

Email: hailiang_1111@tongji.edu.cn.

\section{ABSTRACT}

At present, all documented RecJs are exonucleases, degrading single-stranded 
nucleic acids. Here, we report a novel RecJ, from the extremely alkaliphilic bacterium Bacillus alcalophilus (BaRecJ), which possesses endonuclease activity and can cleave supercoiled DNA. BaRecJ contains the typical DHH and DHHA1 domains, which are conserved in all RecJs, and a functionally unknown PIWI-like domain at the C-terminus. The endonuclease activity originates from the C-terminal domain of BaRecJ which contains PIWI-like domain, and the exonuclease activity from the DHH and DHHA1 domains. Mutational analysis reveals that several important residues affect the endonuclease activity of BaRecJ. Moreover, BaRecJ cleaves specific target sequences at moderate temperature when directed by a phosphorothioate-modified single-stranded DNA (S-modified ssDNA) guide. These findings suggest that BaRecJ is substantially different from any reported RecJs and has the potential to be developed as a new gene editing tool.

Keywords: Bacillus alcalophilus; endonuclease activity; RecJ

As a DHH phosphatase superfamily member, RecJ has long been considered to function on ssDNA or ssRNA as an exonuclease $(1,2)$, and is involved in diverse processes including resecting DNA ends in homologous recombination (HR), degrading the 5'- strand of the DNA unwound by RecQ helicase at double-stranded DNA breaks (3) mediating the excision step (4), reducing homology-facilitated illegitimate recombination events (5), and rescuing stalled replication forks $(6,7)$. RecJ-like can also degrade ssRNA from the 3'-end, and proofread 3'-mismatched 
RNA primers in DNA replication (8).

The enzymatic functions and activities of proteins are greatly influenced by the domains that they contain. RecJ from the bacterium Escherichia coli (EcRecJ), a typical RecJ, possesses DHH, DHHA1 and OB-fold domains, and exhibits 5'- to 3'ssDNA exonuclease activity (9). Thermus thermophilus RecJ (TtRecJ) and Deinococcus radiodurans RecJ (DrRecJ) possess the aforementioned domains and an additional C-terminal element, which contributes to their DNA binding capability $(10,11,12)$. RecJ from the archaeon Pyrococcus furiosus can degrade ssRNA from both the 5'- and 3'- ends, despite only possessing DHH and DHHA1 domains ${ }^{8}$. In contrast, Cdc45, a eukaryotic RecJ homolog, contains DHH and DHHA domains and an additional C-terminal domain; it lacks nuclease activity but has ssDNA binding capability (13). Although RecJ homologous genes have been found in almost all bacteria, archaea and eukaryotes, RecJs have only been shown to degrade ssDNA and ssRNA as exonucleases.

The crystal structures of RecJs from $T$. thermophilus and D. radiodurans have been solved. The structure of TtRecJ reveals a pocket, formed from the OB fold domain. The hole near the active site is too narrow for double-stranded (ds) DNA to fit, ensuring the ssDNA-specificity of TtRecJ $(7,14)$. The structure of DrRecJ shows that the terminus of ssDNA is anchored to the $5^{\prime}$ - phosphate binding pocket above the active site, which is guarded by a helical gateway. This prevents dsDNA from entering the active site, and the OB fold domain is located beside the DNA entrance. The structure suggests that a free 5'- ssDNA is essential for DrRecJ nuclease activity 
In this study, we first report endonuclease activity of Bacillus alcalophilus RecJ

(BaRecJ; WP_003324372.1), and characterize its guide-dependent and

guide-independent cleavage reactions. Obviously different from reported RecJs, other than in the conserved DHH and DHHA1 domains, this protein contains a functionally unknown PIWI-like domain (residues 471-653) at the C-terminus; such a domain is widely present in RecJs of members of the genus Bacillus. In vivo, the expression of BaRecJ affects host cell morphology, growth and survival, and causes a decrease of genomic and plasmid DNA content. Based on this finding, the enzymatic properties of BaRecJ were biochemically characterized in vitro. The results show that BaRecJ cleaves supercoiled plasmid DNA into open circular or linear DNA, or even completely degrades it into nucleotides, indicating its function as a DNA endonuclease and exonuclease. Further analysis of nuclease activities confirmed that the endonuclease activity originates from the C-terminal domain of BaRecJ which contains PIWI-like domain, and the exonuclease activity from the DHH and DHHA1 domains. We also found that S-modified ssDNA can be a guide in guide-dependent DNA cleavage by BaRecJ. Taken together, our findings suggest that the newly identified BaRecJ is substantially different from other reported RecJ proteins. On one hand, it is probably involved in homologous recombination and mismatch repair based on exonuclease activity, and on the other hand, it functions as an endonuclease like Argonaute (Ago) proteins to perform silencing of foreign genes. 


\section{RESULTS AND DISCUSSION}

\section{Expression of BaRecJ decreases transformation efficiency}

As a multidomain protein, RecJ has conserved DHH and DHHA1 domains, which are the catalytic core for RecJ exonuclease activity (16) (Figure 1a and Supplementary Figure 1). Some RecJs also possess a C-terminal domain, and these C-terminal domains confer diverse functions $(7,11)$. In addition to the DHH and DHHA1 domains, BaRecJ possesses a PIWI-like domain at its C-terminus (Figure 1a). The PIWI-like domain possesses endonuclease activity and plays an essential role in RNA-induced silencing $(17,18)$.

To elucidate the functions of RecJ from B. alcalophilus, we cloned and expressed its gene. We found that the transformation efficiency in E. coli BL21 (DE3) was very low when using a constitutive expression vector carrying BarecJ (around 5.3\% compared with empty vector pET-23b $(+) ; P<0.0067)$ (Figure 1b). What caused the low transformation efficiency? We found that plasmids isolated from the above transformants showed profound variation, except in a few regions essential for copy number control and antibiotic resistance (Figure 1c, Supplementary Figure 2 and Supplementary Table 1). Previously reported RecJs only have exonuclease activity, which cannot lead to decreased transformation efficiency (19-22). So, we suggest that BaRecJ has a function different from that of any reported RecJs. It performs endonuclease activity and cleaves at least the plasmid DNA to decrease the tranformation efficiency.

\section{Expression of BaRecJ decreases host cell survival rate and DNA content} Induced expression of BaRecJ in E. coli BL21 (DE3) was carried out to verify its effect on host cells. Isopropyl- $\beta$-D-thiogalactoside (IPTG) induction of BaRecJ 
expression caused the cells to form long filaments (Figure 2a, upper right panel), similar to cells during inhibition of cell division (23). In contrast, induction of expression did not lead to cells harboring control plasmid showing abnormal cell morphology (Figure 2a, lower right panel). The survival rate of cells transformed with the BaRecJ expression vector was $1.3 \%$ of that of cells containing empty vector on plates containing $0.1 \mathrm{mM}$ IPTG $(P<0.0001$; Figure $2 \mathrm{~b})$. In liquid medium, it was found that the surviving number of cells containing BaRecJ decreased by $99 \%$ in 4.0 h, while it increased 108-fold for cells containing empty vector (Figure 2c). In addition, we found that the plasmid and genomic DNA content in cells carrying BaRecJ was lower than that in cells transformed with control vector after induction for $3.0 \mathrm{~h}(P=0.0092$, Figure $2 \mathrm{~d}$, and $P=0.0076$, Figure $2 \mathrm{e})$. Similar results were obtained with BhRecJ (the RecJ homologue from B. halodurans), BoRecJ (from $B$. okhensis), BcRecJ (from B. cereus), and FeRecJ (from Fictibacillus enclensis) (Supplementary Figure 3). These results imply that BaRecJ may cause double strand breaks (DSBs) in plasmid and genomic DNA in E. coli host cells, and lead to a decrease in cellular DNA content and cell death.

\section{Characterization of the nuclease activity of BaRecJ}

To confirm that the effect of BaRecJ toward host cells is due to nuclease activity, we purified BaRecJ protein after inducing expression in E. coli at $16^{\circ} \mathrm{C}$ (Figure 3 a, d). At this temperature, the nuclease activity of BaRecJ was inhibited. In vitro, it was found that BaRecJ can degrade supercoiled plasmid DNAs into open circular or linear ones at 23 to $60^{\circ} \mathrm{C}$ (Figure 3d), and the amount of BaRecJ had a tremendous impact on the degradation efficiency (Figure 3b). When the digestion time or the amount of BaRecJ was increased, a smear could be generated on electrophoresis of BaRecJ-digested plasmid DNA. Supercoiled plasmid was almost completely digested 
within $2 \mathrm{~h}$ when the concentration ratio of enzyme to plasmid substrate was 20:1 (Figure 3c). Digestion was promoted by both $\mathrm{Mg}^{2+}$ and $\mathrm{Mn}^{2+}$ (Figure $3 \mathrm{e}$ and Supplementary Figure 4), and not sensitive to $\mathrm{Cu}^{2+}$ (Supplementary Figure 4), which is similar to findings for many documented RecJ nucleases. But different with other RecJs, the digestion of BaRecJ is not sensitive to $\mathrm{Co}^{2+}(14,24)$. BaRecJ can digest many vectors with different sequences at different rates, including pGADT7, pET-28, pUC57, pTARGET and pCRCT (Figure 3f). BaRecJ can also digest linear dsDNA and generate a smear in electrophoresis (Supplementary Figure 5).

BaRecJ can digest the classical substrate ssDNA from the 5'-terminus, and conserved residues are required for the ssDNA-specific 5'-exonuclease activity. Like in classical RecJ (15), H170 is a key residue that was essential for this BaRecJ exonuclease activity (Figure 4a, left two panels, and Supplementary Table 4). The results of electrophoretic mobility shift assays (EMSAs) support the nuclease activity toward ssDNA substrates (Figure 4b). Among the experimental substrates, ssDNA was bound most strongly by BaRecJ (Figure 4b, left panel), which is consistent with the enzyme having its highest nuclease activity toward this substrate. It was further found that BaRecJ can bind dsDNA; however, it could not digest this substrate (Figure 4a, right two panels). These results imply that BaRecJ has some characteristics of both RecJ and Ago proteins; it has exonuclease activity like a typical RecJ, and endonuclease activity like a prokaryotic Ago (pAgo) protein.

\section{Mutational analysis of endonuclease activity}

To determine the active site of BaRecJ endonuclease activity, we first used online prediction tools. BaRecJ spans residues 1-787, including DHH superfamily (1-550) and ssDNA exonuclease activity superfamily (550-787) domains, and the PIWI-like region near the C-terminus (471-653) (Figure 5a). We recombinantly expressed each 
167 of these fragments of the protein. In vitro, the fragment consisting of residues 168 471-787 retained endonuclease activity toward pUC19-s and pmg36e. It was further 169 found that although the PIWI-like region had some activity toward pUC19-s and 170 pmg36e, it was similar to that of the 653-787 amino acid (aa) segment, and weaker 171 than that of the 471-787 aa segment (Figure 5b, c; Supplementary Figure 6). These 172 data suggest that the DNA chopping activity does not depend on full-length BaRecJ, and the active site for this reaction is contained in the C-terminal fragment of the 174 protein.

RecJ contain a PIWI-like domain, which is an important domain entrust chopping activity in pAgo protein. BaRecJ homologs contain similar PIWI-like regions, which have some similarities with other PIWI proteins and Ago proteins (Supplementary Figure 7). Thus, we tested the activities of homologs of BaRecJ, including BhRecJ, BoRecJ, FeRecJ, and BcRecJ. When we induced expression of these proteins, we 180 found that they also led to death of the host E. coli (Supplementary Figure 8). These results imply that these homologs of BaRecJ are, like BaRecJ itself, endonucleases. It can be inferred that the C-terminal domain which contains PIWI-like domain give rise to the DNA chopping activity. Some of the PIWI domains of Agos have an RNase H-like fold, and their active sites contain a DEDX $(X=N, D$ or $H)$ catalytic tetrad, which confers endonuclease activity on these proteins $(25,26)$. We predicted the 3D structure of $\mathrm{BaRecJ}$ through the RCSB PDB website (http://www.rcsb.org/\#Subcategory-search sequences). It showed that the residues of the DEDX motif was corresponding to D561, E600, L634 and S762 in BaRecJ (Supplementary Figure 9). In vitro, the D561A mutant disrupted the ability of the enzyme to digest plasmid DNA, while the L634A mutant increased the activity, and 191 the mutants of the other two positions had little effect on the activity (Figure 5d, e). 
The increase in activity caused by the mutation may be because it is more favorable for binding to the substrate or catalytic reaction, or the steric hindrance is reduced after the mutation of the inactive site, which is beneficial to the binding of the substrate. In addition, we mutated other positions based on the predicted structure and sequence comparisons. The E640A mutant showed reduced cleavage activity, however, other three mutants E503A, H524A, E560A did not affect the activity (Figure 5f). These results imply that residues D561 and E640 are important for the endonuclease activity of BaRecJ.

\section{BaRecJ can cleave plasmid by using small DNA guides}

Our data show that BaRecJ has endonuclease activity, so how does it cut? We used different guides (25 nucleotides [nt]) for DNA-guided cleavage reactions (Supplementary Figure 10A-C). General and phosphorylated 25-nt single guides resulted in degradation of pUC-19s, as was also observed in the absence of any guide. Use of an S-modified guide resulted in no degradation of pUC19-s plasmid, but a reduction in the amount of supercoiled plasmid and an increase in linearization were obvious. Considering that the protein also has exonuclease activity and the results obtained in DNA-guided cleavage reactions using DNA guides completely matching the target plasmid (Supplementary Figure 10A-C), we decided to test S-modified DNA guides of different lengths and for different reaction times. It was found that with increasing S-modified guide length $(15,20,25$ and $35 \mathrm{nt})$, the rate and extent of degradation of the plasmid were reduced (Supplementary Figure 10D, E). As the reaction time was prolonged, the proportion of open circular and linear plasmid DNA increased (Supplementary Figure 10A-C). Additionally, L634A, the activity increased mutant, also showed improved ability to produce open circular and linear plasmid 
results indicating that the 25 -nt S-modified DNA guide could inhibit the chopping activity of BaRecJ, but enhance the ability of BaRecJ to linearize the plasmid.

To test the specificity of the cleavage position, we used a 25-nt S-modified ssDNA guide with BaRecJ to treat pUC-19s for 1 and $4 \mathrm{~h}$, respectively, and recovered linearized fragments. After ligation, transformation and sequencing, it was found that the mutation (i.e. deletion/insertion) sites were near the guide in the short-term reaction (Figure 6a, b), indicating that the 25-nt S-modified ssDNA guide can bind to the active site and help cleave the plasmid. When the reaction time was prolonged, the mutation site was further away from the position of the guide, and the length of the deletion fragment was increased (Figure $6 \mathrm{c}$, d). It can be concluded that general guides are degraded by BaRecJ, while S-modification decreases degradation of the guide by BaRecJ.

In vivo, BaRecJ can directly interact with plasmid or genomic DNA and cause DNA DSBs, leading to a decrease of DNA content. In vitro, BaRecJ can cleave and degrade circular plasmid DNA. Without a guide DNA, BaRecJ can directly cause 'chopping' (27) and degradation of a plasmid. BaRecJ may be able to degrade these DNAs in a non-specific fashion via guide-independent endonuclease function, similar to that of several Ago proteins, such as the archaeal MjAgo (28); besides canonical guide-dependent endonuclease activity, MjAgo has guide-independent endonuclease activity. This kind of 'chopping' activity would allow BaRecJ to cleave long dsDNA, including circular plasmid DNA and genomic DNA. The resulting cleavage products may then be used as guides for further cleavage of the starting substrate.

Due to the exonuclease activity of BaRecJ, when no modified guide is bound to BaRecJ, the guide can be digested from the terminus, which causes the target plasmid to be cleaved in a guide-independent manner. Thus, it was difficult to verify 
guide-dependent specific endonuclease function using a general guide in vitro. We thus observed the characteristics of the endonuclease activity by undertaking experiments using S-modified guides instead; such modification can inhibit digestion of the guide to some extent. When the guide length reached 25-nt, its digestion by BaRecJ was significantly inhibited, improving the ability of the enzyme to cleave a specific target sequence. Therefore, such modified short DNA fragments can be used as a guide to direct BaRecJ to cleave a specific site. The DHH and DHHA1 domains of BaRecJ bind to the 5'- end of a ssDNA. Based on the principle of base complementation, we suggest that BaRecJ binds to the target strand in a position complementary to the single-stranded guide DNA. BaRecJ then nicks the target single strand of the plasmid, which is bound by the guide, and further nicks the other strand to linearize the plasmid. The linearized fragment is further degraded in the direction from $5^{\prime}-$ to $3 '$-, to finally form a sticky end protruding at the 3 '- end. types of RecJ protein (15). Compered with the typical EcRecJ, BaRecJ also possesses a DHH domain and a DHHAl domain. In addition, BaRecJ possesses a novel PIWI-like domain at the C-terminus, which is different from other Ago and PIWI proteins $(27,28)$. It does not have a conserved DEDX tetrad with endonuclease activity $(25,26,29)$; only the first two residues are conserved - the latter two residues are different from those in the other proteins. BaRecJ exerts endonuclease activity, but

262 its guide-dependent cleavage mechanism is fundamentally different from Agos. It lacks the MID and PAZ domains, which usually form binding pockets that facilitate the anchoring of the 5'- and $3^{\prime}$-ends of an oligonucleotide guide, respectively. In contrast, BaRecJ anchors the guide through the DHH domain and is then directed to the specific cleavage site. 
In B. alcalophilus, canonical RecJ domains and a PIWI-like domain are coupled together to function, but in other bacteria these two proteins are separate. However, it is possible that they work together through protein interactions. Whether BaRecJ is exceptional, or whether genes encoding RecJ and PIWI-like proteins were originally fused but separated and then evolved separately, deserves further study. RecJ and PIWI-like proteins may participate in repair or defense processes through interactions. In particular, the eukaryotic RecJ homologue, Cdc45, which only has ssDNA binding capability (13), is worthy of further study. We believe that BaRecJ contains the classical DHH and DHHA1 domains, which can exert the exonuclease function and cut off mismatched bases, and play a role in the process of DNA mismatch repair. At the same time, BaRecJ, which binds to the mismatch repair site, can also function as an endonuclease to cleave exogenous plasmid DNA or viral DNA near the mismatch repair site, to protect the repair site from interference from foreign DNA and ensure the smooth progress of repair.

As a unique branch of the DHH superfamily, RecJ nucleases with a PIWI-like domain at the C-terminus are widely present in class Bacilli. In future, more research is required for complete understanding of the functional diversity and differentiation of RecJs that have an additional C-terminal domain. These C-terminal domains generally show sequence similarity to Ago proteins, such as the PIWI-like domain in BaRecJ. Here, our results support a novel function of the C-terminal domain in restricting exogenous plasmids. BaRecJ is the first reported RecJ with endonuclease and exonuclease activity, and is possibly involved in maintaining genome stability. BaRecJ can perform DNA-guided cleavage of target DNA in vitro at a wide range of temperatures; it functions efficiently at $37^{\circ} \mathrm{C}$. Therefore, it can potentially be used for genome editing and selective cleavage of dsDNA targets from cells of mesophilic 
organisms. A putative mechanism of action by BaRecJ was proposed (Figure 7).

\section{CONCLUSION}

In this study, we find that BaRecJ is extremely different from other $\mathrm{DHH}$ superfamily members $[25,26]$. It uniquely exhibits endonuclease activity, cleaving dsDNA and causing mutation and even cell death. According to the experiment in vitro, BaRecJ cleaves supercoiled plasmid into open circular and linear plasmid, and completely degrades the supercoiled plasmid into nucleotides. The activity of BaRecJ is influenced by temperature and the concentration of $\mathrm{Mg} 2+$. While the influence of other metal ions remains to be further studied. In vivo the basal level of BaRecJ (without induction) makes cells form the long filaments but not influences the cell survival; in contrast, a high content of BaRecJ (after IPTG induction) influences the cell survival, causing the cell death and less filaments. Moreover, BaRecJ cleaves specific target sequences at moderate temperature when directed by a phosphorothioate-modified single-stranded DNA (S-modified ssDNA) guide. These findings suggest that BaRecJ is substantially different from any reported RecJs and we believe that once the regulation mechanism of BaRecJ is deciphered, it can be applied in diverse fields in the future.

\section{Experimental Procedures}

\section{Culture of Bacillus alcalophilus}

B. alcalophilus CGMCC 1.3604 (ATCC27647) was purchased from the China

312 General Microbiological Culture Collection Center and cultivated in maltose/peptone/yeast extract medium $(1.0 \%$ maltose, $0.5 \%$ peptone, $0.1 \%$ yeast 


\section{Plasmid construction and transformation}

316 The gene encoding BaRecJ (aa 1-787) was amplified by PCR from $B$.

317 alcalophilus genomic DNA (Supplementary Table 1). PCR product was cloned 318 into pMD18-T and confirmed by DNA sequencing. The BarecJ DNA fragment 319 was further subcloned into constitutive expression vector pET-23b(+) between 320 NdeI and XhoI sites, yielding pET23BaRecJ, and into inducible vectors 321 pACYCDuet-1 and pET28a between NdeI and XhoI sites, generating 322 pACYCBaRecJ and pET28BaRecJ respectively. Plasmids for expressing 323 site-directed mutants of BaRecJ were constructed using phosphorothioate-based 324 ligase-independent gene cloning, as previously described (30). RecJs from other species $(\mathrm{Bh}, \mathrm{Bc}, \mathrm{Bo}, \mathrm{Fe}, \mathrm{Sg})$ were treated in the same way.

\section{Analysis of transformation efficiency}

E. coli BL21 (DE3) competent cells were spread on LB-agar plates containing $100 \mu \mathrm{g} \mathrm{ml} l^{-1}$ ampicillin and $50 \mu \mathrm{g} \mathrm{ml}^{-1}$ chloramphenicol to select cells harboring pET-23b(+) and pACYCDuet-1 respectively. Transformation efficiency of pET-23b and pET23BaRecJ was calculated on the basis of the number of

331 colony-forming units (CFU) per $\mu \mathrm{g}$ DNA. To compare transformation efficiency, the number of CFU for pET23BaRecJ was defined as 1, with the number of CFU 333 for pET-23b(+) normalized to this value. The sequence of plasmids from 334 surviving transformants was confirmed by traditional Sanger sequencing by 335 Personal Biotechnology Company (Shanghai, China). Primers used are listed in 336 Supplementary Table 2.

DNA content assay 


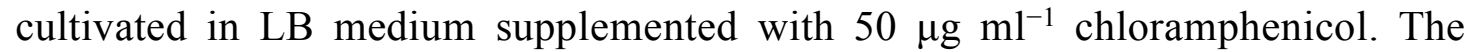

340 culture was collected after induction for $3 \mathrm{~h}$ and used to extract plasmid and

341 genomic DNA using an E.Z.N.A. ${ }^{\circledR}$ Plasmid Mini Kit I (Omega) and an

342 E.Z.N.A.® Bacterial DNA Kit (Omega), respectively, according to the user

343 manuals. After preliminary confirmation of the quality of the DNA on a $0.8 \%$

344 agarose gel, the plasmid and genomic DNAs were quantified using a BioTeke

345 ND5000 spectrophotometer. RecJs from other species (Bh, Bc, Bo, Fe) were

346 assessed in the same way.

\section{Bacterial survival assay}

E. coli BL21 (DE3) colonies containing pACYCBaRecJ or empty vector (pACYCDuet-1) were selected to prepare suspensions, respectively. Appropriate volumes of suspensions were spread onto LB agar plates containing $0.1 \mathrm{mM}$

351 IPTG and $50 \mu \mathrm{g} \mathrm{ml} l^{-1}$ chloramphenicol, and cultivated at $37^{\circ} \mathrm{C}$; then $\mathrm{CFU}$ were counted. To identify the effect of BaRecJ on survival rate, the number of CFU for plasmid pACYCBaRecJ was defined as 1, and the number of CFU for pACYCBDuet1-1 was normalized based on the value for pACYCBaRecJ. The effect of induction time on survival rate was studied by inducing bacteria harboring pACYCDuet-1 or pACYCBaRecJ with IPTG for increasing periods of time. The colonies were inoculated into LB medium containing $0.1 \mathrm{mM}$ IPTG and $50 \mu \mathrm{g} \mathrm{ml} l^{-1}$ chloramphenicol and cultivated at $37^{\circ} \mathrm{C}$ with shaking. Samples were taken every hour for $8 \mathrm{~h}$. The samples were centrifuged at $13,000 \times g$ for $3 \mathrm{~min}$ and washed three times at room temperature to remove IPTG. The resuspensions

361 were spread on LB-agar plates, cultivated at $37^{\circ} \mathrm{C}$ overnight, then $\mathrm{CFU}$ per ml

362 were counted. Transformants containing pET28BaRecJ and its mutants or empty vector (pET28a) were selected and grown to the same $\mathrm{OD}_{600}$. The diluted 
bacterial suspensions of different strains were spotted onto LB-agar containing 50

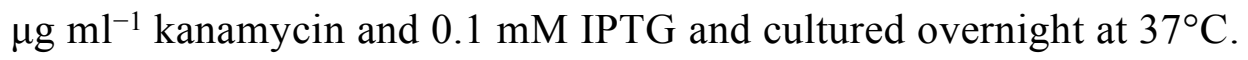

\section{Expression and purification of BaRecJ and its mutants}

Recombinant expression plasmids were transformed into E. coli BL21 (DE3) competent cells (Supplementary Table 3). Transformants were cultivated in LB

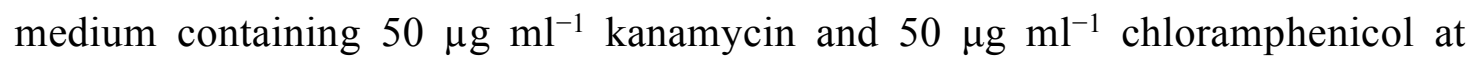
$37^{\circ} \mathrm{C}$ in a shaking incubator and grown to an $\mathrm{OD}_{600}$ of $0.5-0.6$. The cells were cold-shocked by incubating in an ice bath for 20 min. Protein expression was induced for $16 \mathrm{~h}$ at $16^{\circ} \mathrm{C}$ by adding IPTG to a final concentration of $0.2 \mathrm{mM}$. Cells were harvested by centrifugation. Recombinant proteins were purified via immobilized $\mathrm{Ni}^{2+}$-affinity chromatography as follows: the bacterial pellet was suspended in lysis buffer $(50 \mathrm{mM}$ Tris-HCl, $\mathrm{pH} 8.0,0.5 \mathrm{M} \mathrm{NaCl}, 20 \mathrm{mM}$ imidazole) and disrupted by sonication. The cell extract was clarified by centrifugation at $13,000 \times g$ for $30 \mathrm{~min}$. The supernatant was loaded onto a resin-containing column pre-equilibrated with lysis buffer and washed with $>100$ column volumes of lysis buffer containing $20 \mathrm{mM}$ imidazole. The bound protein was eluted from the column using elution buffer $(50 \mathrm{mM}$ Tris- $\mathrm{HCl}, \mathrm{pH} 8.0,0.5 \mathrm{M}$ $\mathrm{NaCl}, 250 \mathrm{mM}$ imidazole). The affinity-purified proteins were polished by gel-filtration chromatography using Superdex G200. After checking the purity of the eluate by $15 \%$ SDS-PAGE, the protein was dialyzed into storage buffer (50 $\mathrm{mM}$ Tris- $\mathrm{HCl}, \mathrm{pH} 8.0,0.15 \mathrm{M} \mathrm{NaCl}$ and $30 \%$ glycerol) and stored in small aliquots at $-80^{\circ} \mathrm{C}$.

\section{Nuclease activity assays}

Nuclease activity toward dsDNA was characterized as described with some 
modifications ${ }^{15,26}$. Plasmid DNA, PCR-amplified linear DNA, or genomic DNA was used as substrate. Except in the titration assay of BaRecJ, all reactions were performed with a concentration ratio of substrate to BaRecJ of $1: 20$ at $37^{\circ} \mathrm{C}$. Titration of plasmid to BaRecJ was performed with concentration ratios 1:1, 1:5, 1:10, 1:20, and 1:40. To determine the metal ion preference of BaRecJ, digestion of plasmid DNA by BaRecJ was performed at different concentrations of $\mathrm{Mg}^{2+}(0.1$, $1,5,10,50 \mathrm{mM})$ in buffer $(10 \mathrm{mM}$ Tris- $\mathrm{HCl}, \mathrm{pH} 8.0,50 \mathrm{mM} \mathrm{NaCl}$ and $10 \mathrm{mM}$ dithiothreito (DTT)) at $37^{\circ} \mathrm{C}$ for $2 \mathrm{~h}$. After optimization of the divalent ion concentration, the reaction buffer consisted of $10 \mathrm{mM}$ Tris- $\mathrm{HCl}, \mathrm{pH} 8.0,50 \mathrm{mM}$

$\mathrm{NaCl}, 10 \mathrm{mM} \mathrm{MgCl} 2$ and $10 \mathrm{mM}$ DTT. The reactions were stopped by adding an equal volume of $50 \mathrm{mM}$ ethylenediaminetetraacetic acid (EDTA), and incubated for $15 \mathrm{~min}$ at $65^{\circ} \mathrm{C}$. Reaction products were analysed on $1 \%$ agarose gels. Gels were stained with 4S Red Plus Nucleic Acid Stain (BBI Life Sciences), visualized under a GelDoc XR system, and analysed using Image Lab software (Bio-Rad). Nuclease activity toward single-stranded oligonucleotides and oligoribonucleotides, as well as their double-stranded forms (Supplementary Table 4), was characterized similarly to the method described above for dsDNA. The reactions were performed at $37^{\circ} \mathrm{C}$ for $30 \mathrm{~min}$ in reaction buffer consisting of $10 \mathrm{mM}$ Tris-HCl, $\mathrm{pH} 8.0,50 \mathrm{mM} \mathrm{NaCl}, 10 \mathrm{mM} \mathrm{MgCl}_{2}$ and $10 \mathrm{mM}$ DTT. After 407 incubation, an equal volume of stopping buffer ( $90 \%$ formamide, $100 \mathrm{mM}$ EDTA and $408 \quad 0.2 \%$ sodium dodecyl sulfate) was added to the reactions. Then, the reaction mixtures were subjected to $8 \mathrm{M}$ urea-denaturing $15 \%$ PAGE to separate the products. Finally,

410 the gels were imaged and quantified using an FL9500 fluorescence scanner (GE 411 Healthcare). EMSA experiments were used to characterize the binding capability 412 of BaRecJ and the BaRecJ H170A mutant to oligonucleotides and 
oligoribonucleotides, as well as their double-stranded forms. During EMSA assays, $\mathrm{MnCl}_{2}$ in the buffer was replaced with $\mathrm{CaCl}_{2}$, and $10 \%$ native PAGE was run to detect potential protein-substrate complexes.

Supercoiled plasmid DNA was used as the target in DNA-guided cleavage assays (Supplementary Table 5). The reactions were performed at molar ratio 1:20:30 target:protein:guide at $37^{\circ} \mathrm{C}$ for 1 or $4 \mathrm{~h}$. BaRecJ $(500 \mathrm{nM})$ was mixed with $750 \mathrm{nM}$ guide DNA in reaction buffer consisting of $10 \mathrm{mM}$ Tris- $\mathrm{HCl}, \mathrm{pH} 8.0,50 \mathrm{mM} \mathrm{NaCl}$, $10 \mathrm{mM} \mathrm{MgCl} 2$ and $10 \mathrm{mM} \mathrm{DTT}$, and incubated at $37^{\circ} \mathrm{C}$ for $20 \mathrm{~min}$ for guide reloading. The target plasmid DNA was added to a final concentration of $25 \mathrm{nM}$. Reactions were analysed on 1\% agarose gels. Gels were stained with 4S Red Plus Nucleic Acid Stain, visualized under a GelDoc XR system and analysed using Image Lab software. The obtained linearized plasmid was excised from the agarose gel and purified using a MiniBEST Agarose Gel DNA Extraction Kit (Takara Bio). The cohesive ends of the linearized plasmid were blunt-ended and self-ligated using a DNA Blunting Kit (Code No. 6025, Takara Bio). The DNA Blunting Kit can smooth DNA with 3'- or 5'- protruding ends; T4 DNA polymerase, one of components in the kit, has 5'- to $3^{\prime}$ - polymerase activity and 3'- to 5'- exosomal enzyme activity. The resulting blunt-ended DNA can be efficiently ligated using the ligation solution in the kit. The ligation product was then transformed into competent E. coli DH5 $\alpha$ cells (Takara Bio), and after $16 \mathrm{~h}$ of culture, selected clones were sent for sequencing (Sangon Biotech).

\section{Statistical analysis}

All P-values were calculated by Student's $t$-test using SPSS software version 22.0. Statistical significance was accepted at the $95 \%$ confidence level, which 
meant that a difference was considered significant if $\mathrm{P}<0.05$. The $\mathrm{P}$-values of transformation efficiencies were calculated by inputting the number of CFU from biological triplicates of plasmid-bearing cells. In survival experiments, the number of CFU from biological triplicates of transformants cultivated on the plate was used as the input. The P-values for plasmid and genome DNA content were obtained by inputting the plasmid and genome DNA yields from biological triplicates of transformants after 3-h induction.

\section{ACKNOWLEDGMENTS}

445 This work was supported by the National Key R\&D Program of China (Grant No. 446 2018YFC0310701), the Natural Science Foundation of China (Grant No. 31671539, 31370214), the Stem Cell Strategy Library and Clinical Transformation Platform of Stem Cell Technology in Shanghai Zhangjiang National Independent Innovation Demonstration Zone (ZJ2108-ZD-004).

\section{REFERENCES}

1. Nagata, M.; Ishino, S.; Yamagami, T.; Ogino, H.; Simons, J. R.; Kanai, T.; Atomi, H.; Ishino,

3. Morimatsu, K.; Kowalczykowski, S.C. (2014) RecQ helicase and RecJ nuclease provide Y. (2017) The Cdc45/RecJ-like protein forms a complex with GINS and MCM, and is important for DNA replication in Thermococcus kodakarensis. Nucleic Acids Res 45, 10693-10705.

2. Li, Z.; Pan, M.; Santangelo, T. J.; Chemnitz, W.; Yuan, W.; Edwards, J.L.; Hurwitz, J.; Reeve, J.N.; Kelman, Z. (2011) A novel DNA nuclease is stimulated by association with the GINS complex. Nucleic Acids Res 39, 6114-6123. complementary functions to resect DNA for homologous recombination. Proc. Natl. Acad. Sci. USA 111, 5133-5142.

4. Viswanathan, M.; Burdett, V.; Baitinger, C.; Modrich, P.; Lovett, S.T. (2001) Redundant exonuclease involvement in Escherichia coli methyl-directed mismatch repair. J. Biol. Chem 
276, $31053-31058$.

5. Harms, K.; Schon, V.; Kickstein, E.; Wackernagel, W. (2007) The RecJ DNase strongly suppresses genomic integration of short but not long foreign DNA fragments by homology-facilitated illegitimate recombination during transformation of Acinetobacter baylyi. Mol. Microbiol 64, $691-702$.

6. Rudolph, C.J.; Upton, A.L.; Lloyd, R.G. (2008) Maintaining replication fork integrity in UV-irradiated Escherichia coli cells. DNA Repair 7, 1589 - 1602.

7. Wakamatsu, T.; Kitamura, Y.; Kotera, Y.; Nakagawa, N.; Kuramitsu, S.; Masui, R. (2010) Structure of RecJ exonuclease defines its specificity for single-stranded DNA. J. Biol. Chem 285, 9762-9769.

8. Yuan, H.; Liu, X.P.; Han, Z.; Allers, T.; Hou, J.L.; Liu, J.H. (2013) RecJ-like protein from Pyrococcus furiosus has 3'-5' exonuclease activity on RNA: implication of its proofreading capacity on 3'-mismatched RNA primer in DNA replication. Nucleic Acids Res 41, $5817-5826$.

9. Lovett, S.T.; Kolodner, R.D. (1989) Identification and purification of a single-stranded DNA-specific exonuclease encoded by the recJ gene of Escherichia coli. Proc Natl Acad Sci USA 86, 2627-2631.

10. Yamagata, A.; Masui, R.; Kakuta, Y.; Kuramitsu, S.; Fukuyama, K. (2001) Overexpression, purification and characterization of RecJ protein from Thermus thermophilus HB8 and its core domain. Nucleic Acids Res 29, 4617-4624.

11. Cheng, K.; Zhao, Y.; Chen, X.; Li, T.; Wang, L.; Xu, H.; Tian, B.; Hua, Y. (2015) A Novel C-Terminal Domain of RecJ is Critical for Interaction with HerA in Deinococcus radiodurans. Front. Microbiol 6, 1302.

12. Jiao, J.; Wang, L.; Xia, W.; Li, M.; Sun, H.; Xu, G.; Tian, B.; Hua, Y. (2012) Function and biochemical characterization of RecJ in Deinococcus radiodurans. DNA Repair 11, 349-356.

13. Makarova, K.S.; Koonin, E.V.; Kelman, Z. (2012) The CMG (CDC45/RecJ, MCM, GINS) complex is a conserved component of the DNA replication system in all archaea and eukaryotes. Biol. Direct. 7, 7.

14. Yamagata, A.; Kakuta, Y.; Masui, R.; Fukuyama, K. (2002) The crystal structure of 
exonuclease $\mathrm{RecJ}$ bound to $\mathrm{Mn}^{2+}$ ion suggests how its characteristic motifs are involved in exonuclease activity. Proc Natl Acad Sci USA 99, 5908 - 5912.

15. Cheng, K.; Xu, H.; Chen, X.; Wang, L.; Tian, B.; Zhao, Y.; Hua, Y. (2016) Structural basis for DNA 5'-end resection by RecJ. Elife 5, e14294.

16. Aravind, L.; Koonin, E.V. (1998) A novel family of predicted phosphoesterases includes Drosophila prune protein and bacterial RecJ exonuclease. Trends Biochem. Sci 23, 17-19.

17. Ma, J. B.; Yuan, Y. R.; Meister, G.; Pei, Y.; Tuschl, T.; Patel, D.J. (2005) Structural basis for 5'-end-specific recognition of guide RNA by the A. fulgidus Piwi protein. Nature 434, $666-670$.

18. Parker, J. S.; Roe, S. M.; Barford, D. (2005) Structural insights into mRNA recognition from a PIWI domain-siRNA guide complex. Nature 434, 663-666.

24. Sharma, R., Rao, D.N. (2009) Orchestration of Haemophilus influenzae RecJ exonuclease by interaction with single-stranded DNA-binding protein. J. Mol. Biol 385, 1375-1396. 
Prokaryotic Argonaute Proteins. mBio 9.

26. Swarts, D.C.; Makarova, K.; Wang, Y.; Nakanishi, K.; Ketting, R.F.; Koonin, E.V.; Patel, D.J.; and van der Oost, J. (2014) The evolutionary journey of Argonaute proteins. Nature structural \& molecular biology 21, 743-753.

27. Swarts, D.C.; Szczepaniak, M.; Sheng, G.; Chandradoss, S.D.; Zhu, Y.; Timmers, E.M.; Zhang, Y.; Zhao, H.; Lou, J.; Wang, Y., et al. (2017) Autonomous Generation and Loading of DNA Guides by Bacterial Argonaute. Molecular Cell 65(6), 985-998.e6.

28. Zander, A.; Willkomm, S.; Ofer, S.; Van, W.M.; Egert, L.; Buchmeier, S.; Stöckl, S.; Tinnefeld, P.; Schneider, S.; and Klingl, A.; et al. (2017) Guide-independent DNA cleavage by archaeal Argonaute from Methanocaldococcus jannaschii. Nature microbiology 2(6), 17034.

29. Kuzmenko, A.; Yudin, D.; Ryazansky, S.; Kulbachinskiy, Andrey.; Aravin, A.A. (2019) Programmable DNA cleavage by Ago nucleases from mesophilic bacteria Clostridium butyricum and Limnothrix rosea. Nucleic Acids Res 47 (11), 5822-5836.

30. Blanusa, M.; Schenk, A.; Sadeghi, H.; Marienhagen, J.; Schwaneberg, U. (2010) Phosphorothioate-based ligase-independent gene cloning (PLICing): An enzyme-free and sequence-independent cloning method. Anal Biochem 406, 141-146. 
a

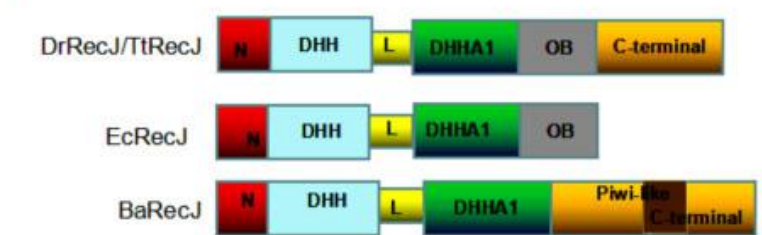

c

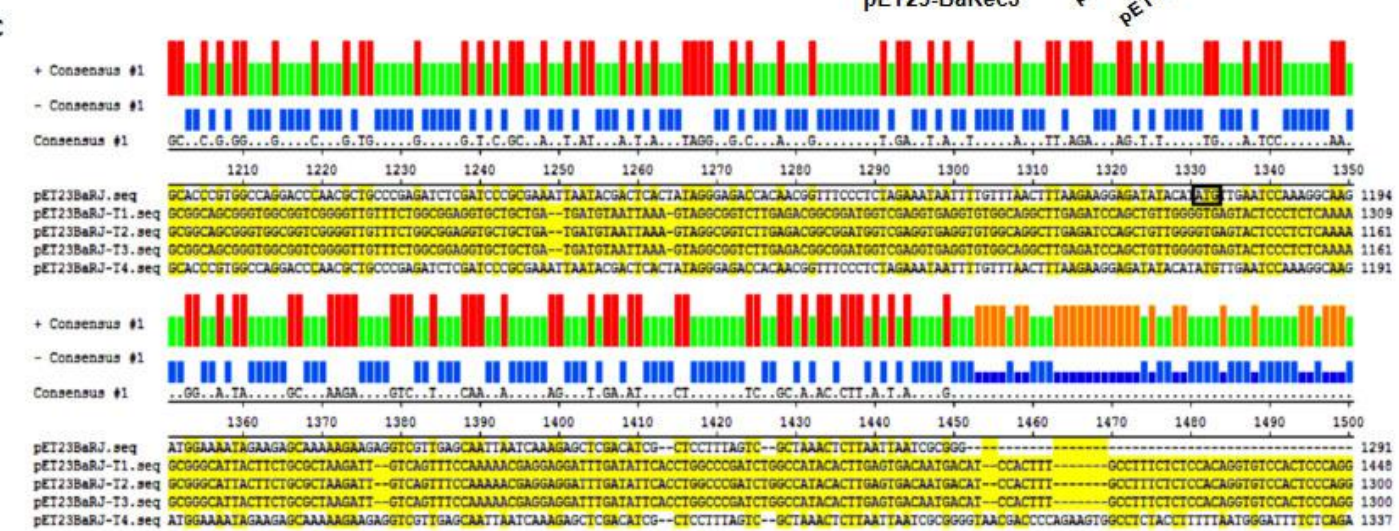

b
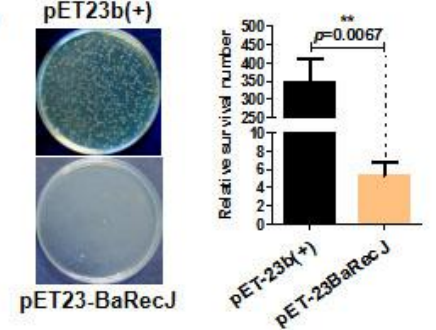

Figure 1. Effect of Bacillus alcalophilus RecJ (BaRecJ) expression on plasmid DNA in Escherichia coli. a Schematic representation of RecJ family members. Dr, Tt, Ec and $\mathrm{Ba}$ are Deinococcus radiodurans, Thermus thermophilus, E. coli and B. alcalophilus, respectively. N, DHH, DHHA1, OB, PIWI-like and C-terminal denote the main structural domains; $\mathrm{L}$ is a linker. The dark shaded area shows the sequence overlap between the PIWI-like domain and the C-terminal domain in BaRecJ. b $E$. coli BL21 (DE3) harboring pET23b(+) and pET23BaRJ were respectively cultured overnight. Appropriate volumes of cultures were spread onto plates containing $50 \mu \mathrm{g}$ $\mathrm{ml}^{-1}$ ampicillin and incubated at $37^{\circ} \mathrm{C}$ overnight. The Figure shows comparison of the transformation efficiency of $E$. coli BL21 (DE3) transformed with either pET-23b $(+$ ) or pET23BaRecJ (Supplementary Data Table 1). Error bars show standard deviations. c Sequence alignment of pET23BaRecJ with sequences of pET23BaRecJT1 to T4; the plasmids pET23BaRecJT1 to T4 were respectively isolated from transformants surviving on the ampicillin-containing agar plates. ATG, the start codon of the BarecJ gene, is boxed. Red columns indicate unmutated bases (identical between the five plasmids), orange and green columns denote mutated bases. 
a

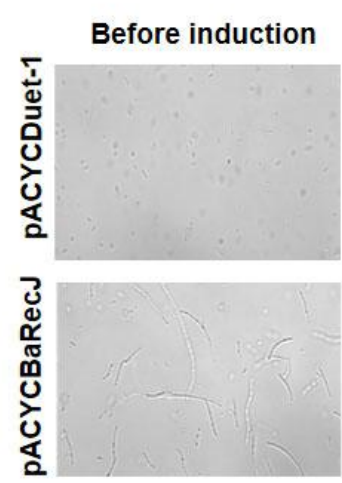

C

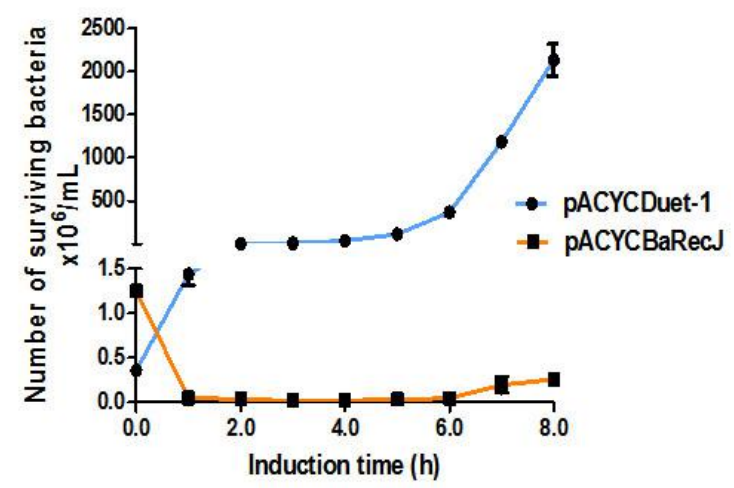

b

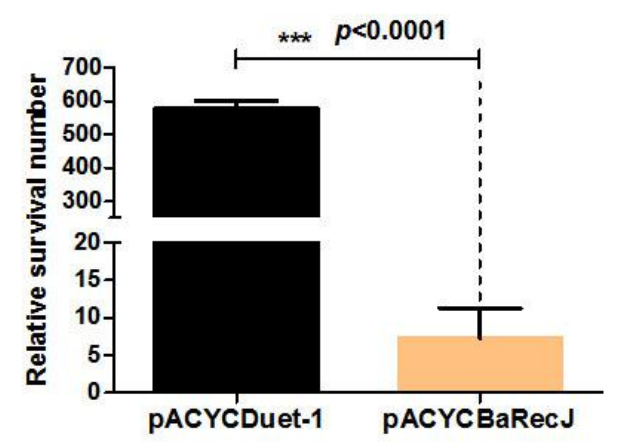

d

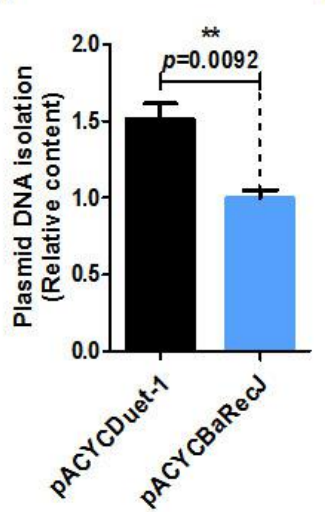

$\mathbf{E}$

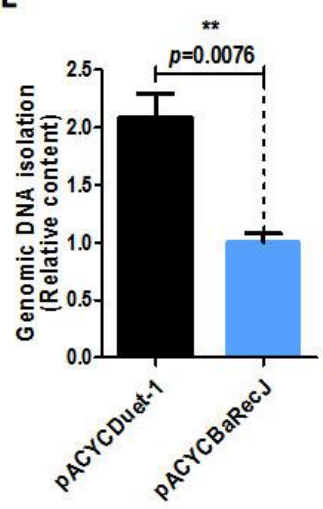

Figure 2. Expression of BaRecJ decreases E. coli cell survival rate and changes cell morphology. a Differences in morphology of E. coli BL21 (DE3) transformants with pACYCDuet-1 (lower) and pACYCBaRecJ (upper). The cultures were imaged under a microscope $(40 \times)$ without (left panel) isopropyl- $\beta$-D-thiogalactoside (IPTG) induction or with (right panel) IPTG induction, respectively. b Comparison of surviving numbers of transformants with pACYCBaRecJ or pACYCDuet-1. All transformants were cultivated overnight with IPTG induction. c Survival curves of transformants with pACYCBaRecJ and pACYCDuet-1, respectively. d Plasmid and genomic DNAs were extracted from the same amount of biomass of E. coli induced for $3 \mathrm{~h}$, respectively. Error bars depict standard deviations of biological triplicates. 
a

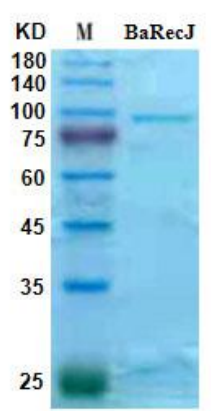

d

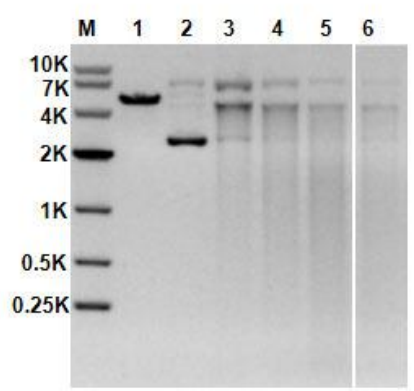

b

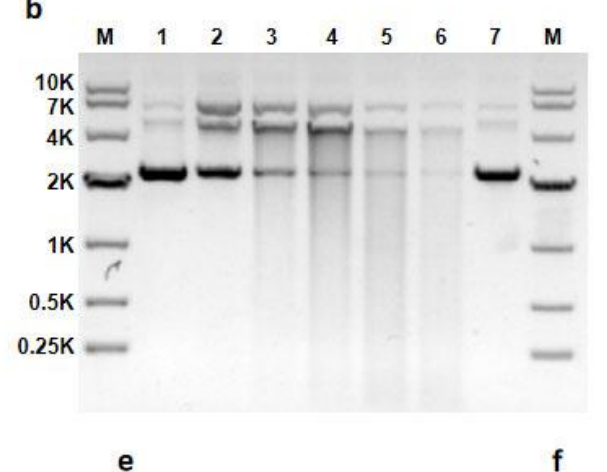

C
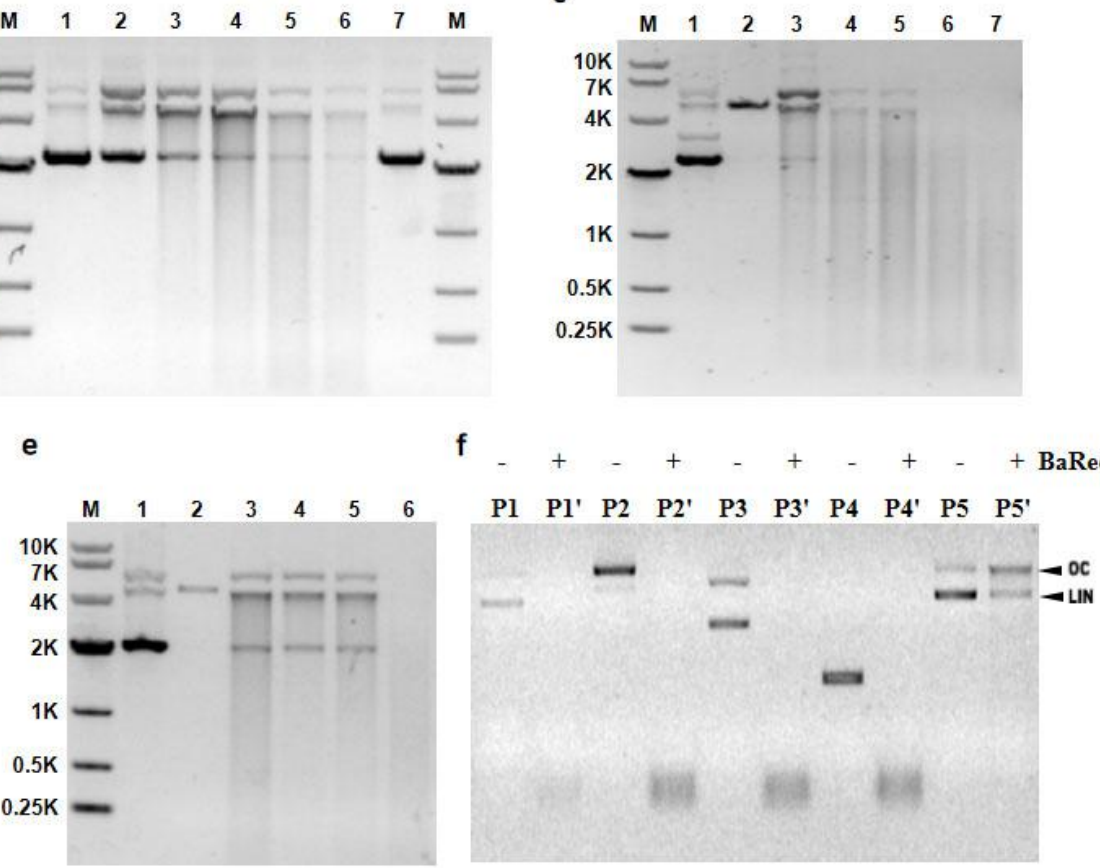

603

Figure 3. Characterization of the nuclease activity of BaRecJ toward plasmid DNA. a Purity analysis of recombinant RecJs by $15 \%$ SDS-PAGE. b Titration of BaRecJ with pUC19-s. BaRecJ was incubated with vector pUC19-s at $37^{\circ} \mathrm{C}$ for $2 \mathrm{~h}$. The molar ratios of BaRecJ to pUC19-s were 1:1, 5:1, 10:1, 20:1, and 40:1 with enzyme concentration $250 \mathrm{nM}$ (lanes 2-6). c Time course of BaRecJ activity toward pUC19-s at $37^{\circ} \mathrm{C}$. The molar ratio of BaRecJ to pUC19-s was 20:1 with enzyme concentration 500 nM. Lane 1: pUC19-s control linearized with EcoRI. Lane 2: pUC19-s control plasmid. Lanes 3-7: pUC19-s digested for 30, 60, 90, 120, and $180 \mathrm{~min}$ by BaRecJ, respectively. d Effect of temperature on the activity of BaRecJ toward pUC19-s. The molar ratio of BaRecJ to pUC19-s was 20:1 with enzyme concentration $500 \mathrm{nM}$. The incubation time was $2 \mathrm{~h}$. Lanes 3-6: 23, 30, 37 and $60^{\circ} \mathrm{C}$, respectively. e Effect of $\mathrm{Mg}^{2+}$ on the activity of BaRecJ. The reactions were performed at $37^{\circ} \mathrm{C}$ for $2 \mathrm{~h}$ with $0.1,1,5$ and $10 \mathrm{mM} \mathrm{Mg}^{2+}$ (lanes 3-6, respectively). The molar ratio of BaRecJ to pUC19-s was 20:1 and the enzyme concentration was $500 \mathrm{nM}$. f Nuclease activity of BaRecJ toward various plasmids. The reactions were incubated at $37^{\circ} \mathrm{C}$ for $3 \mathrm{~h}$. P1, P2, P3, P4, and P5 denote pGADT7, pET-28, pUC57, pTARGET, and pCRCT, respectively. 


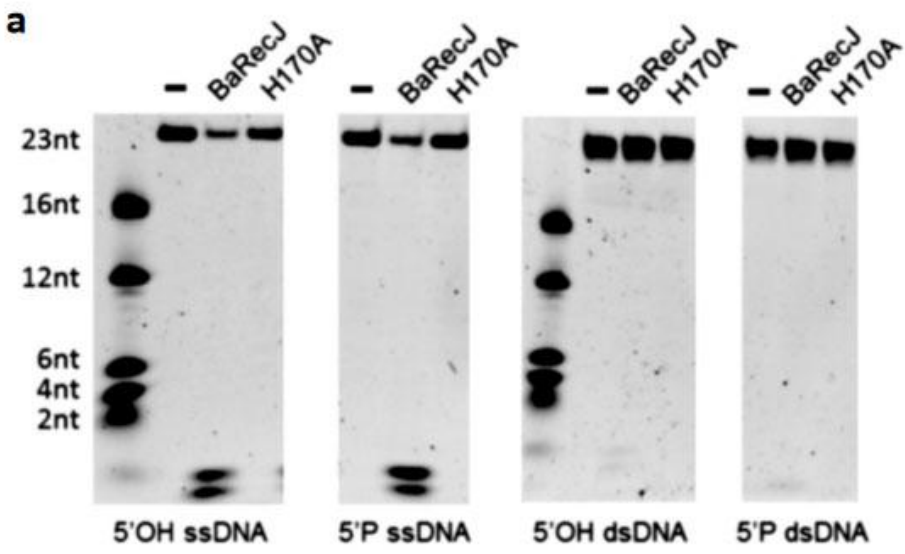

624 Figure 4. The exonuclease activity of BaRecJs toward single-stranded and 625 double-stranded oligodeoxyribonucleotides. a Various oligodeoxyribonucleotides (2.5 626 pmol) in single-stranded or double-stranded form were incubated with 2.5 pmol 627 enzyme at $37^{\circ} \mathrm{C}$ for $20 \mathrm{~min}$. b Binding capability of BaRecJs to various 628 oligodeoxyribonucleotides in single-stranded or double-stranded form. In 629 electrophoretic mobility shift assays, $\mathrm{Ca}^{2+}$ was used in the reaction buffer instead of $630 \mathrm{Mn}^{2+}$ to prevent the cleavage of substrates. 
a

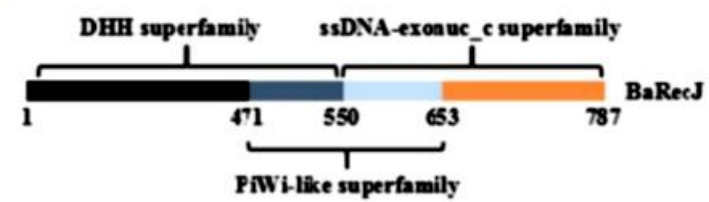

b
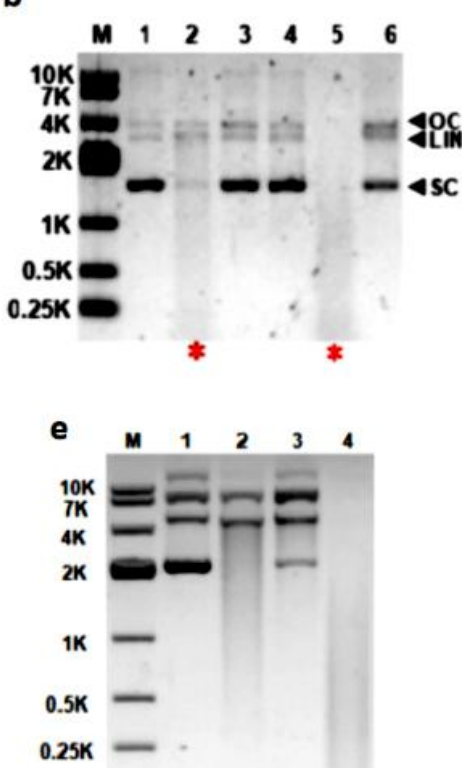

c

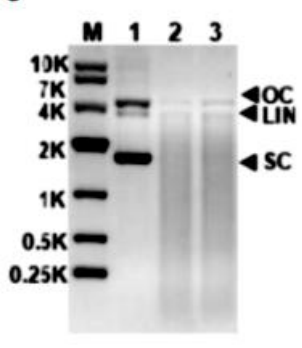

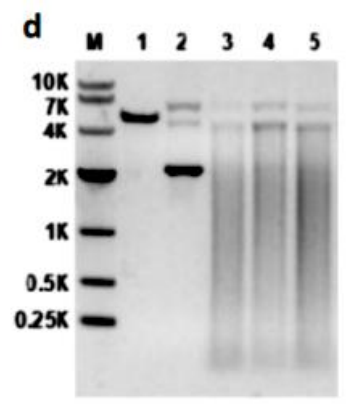

641

642

643

644

645

646

647

648

649

650

651

652

653

654

655

656

657

658

Figure 5. The endonuclease activity of truncations and point mutants of BaRecJ. a Schematic representation of BaRecJ. b, c Electrophoresis of the final plasmid degradation products of wild-type BaRecJ and its truncations (500 nM protein, $750 \mathrm{ng}$ plasmid DNA, cleavage for $2 \mathrm{~h}$ at $37^{\circ} \mathrm{C}$ ). (b), Lanes 1-6: pmg36e control plasmid, pmg36e cleaved by wt BaRecJ, and pmg36e cleaved by fragments of BaRecJ consisting of amino acids (aa) 1-241, aa 241-471, aa 471-787, and aa 1-471, respectively. (c), Lanes 1-3: pmg36e control plasmid, pmg36e cleaved by wt BaRecJ, and pmg36e cleaved by a fragment of BaRecJ consisting of aa 471-653. d, e, f Electrophoresis of the final plasmid degradation products of wt BaRecJ and its mutants (500 $\mathrm{nM}$ protein, $750 \mathrm{ng}$ plasmid DNA, cleavage for $2 \mathrm{~h}$ at $\left.37^{\circ} \mathrm{C}\right)$. (d), Lanes 1-5: pUC19-s linearized with EcoRI, pUC19-s control plasmid, pUC19-s cleaved by wt BaRecJ, and pUC19-s cleaved by BaRecJ E600A mutant or S762A mutant. (e), Lanes 1-4: pUC19-s control plasmid, pUC19-s cleaved by wt BaRecJ, and pUC19-s cleaved by BaRecJ D561A mutant or L634A mutant. (f), Lanes 1-8: pUC19-s linearized with EcoRI, pUC19-s control plasmid, pUC19-s cleaved by wt BaRecJ, and pUC19-s cleaved by BaRecJ E503A mutant, H524A mutant, E560A mutant, E640A mutant, and E560A/E640A double mutant, respectively. 
a

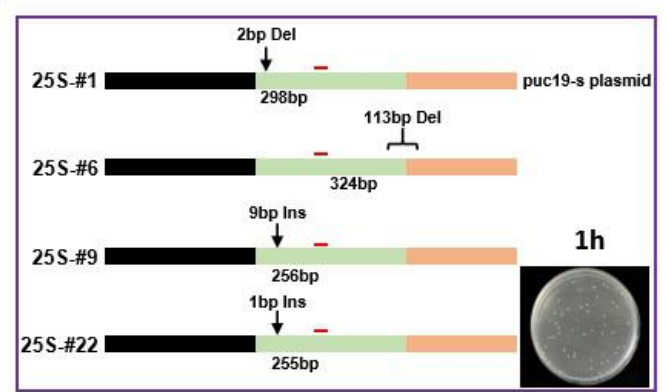

C

659

660

661

662

663

664

665

666

667

668

669

670

671

672

673 the guide site. b

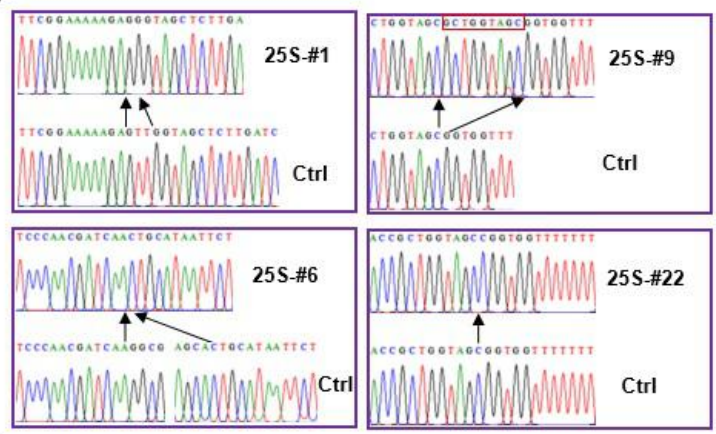

d
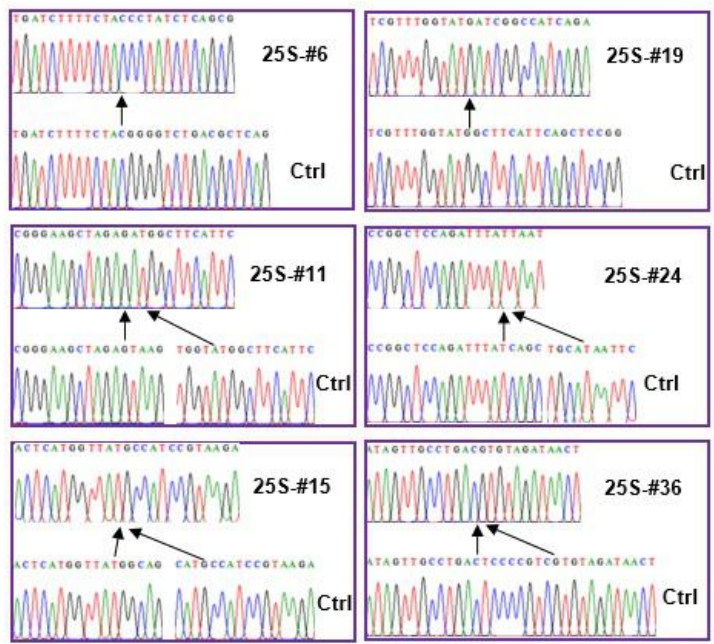

4h

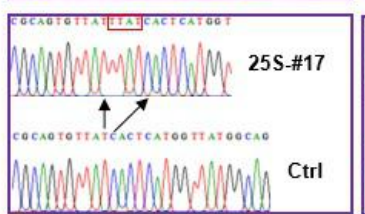

Figure 6. Sequence change of plasmid cleaved by BaRecJ using a guide. a Examples of sequencing results after DNA-guided cleavage of pUC19-s DNA, which shows that deletions and insertions were randomly produced near the guide/target region (500 $\mathrm{nM} \mathrm{BaRecJ}, 10 \mu \mathrm{g}$ plasmid DNA, cleavage for $1 \mathrm{~h}$ at $37^{\circ} \mathrm{C}$ ). b Representative sequencing results after $1 \mathrm{~h}$ of cleavage. c Examples of sequencing results after DNA-guided cleavage of pUC19-s DNA, which show that deletions and insertions were randomly produced near the guide/target region (500 nM BaRecJ, $10 \mu \mathrm{g}$ plasmid DNA, cleavage for $4 \mathrm{~h}$ at $37^{\circ} \mathrm{C}$ ). d Representative sequencing results after $4 \mathrm{~h}$ of cleavage. The above results are from 60 independent experiments. - Represents 
674

676

677

678

679

680

681

682

683

684

685

686

687

688

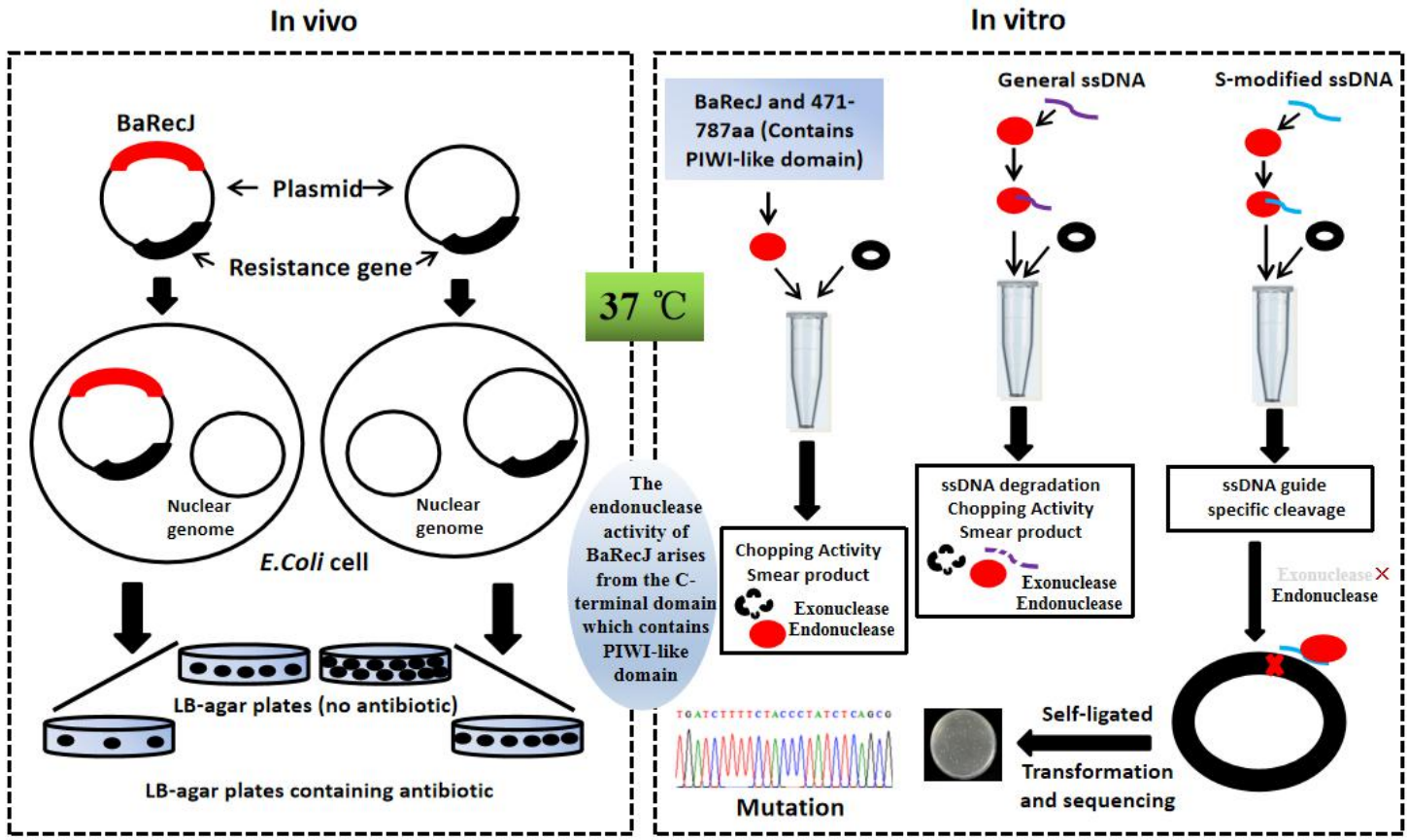

Note: BaRecs $\odot$ Plasmid

Figure 7. A putative mechanism of action by BaRecJ 


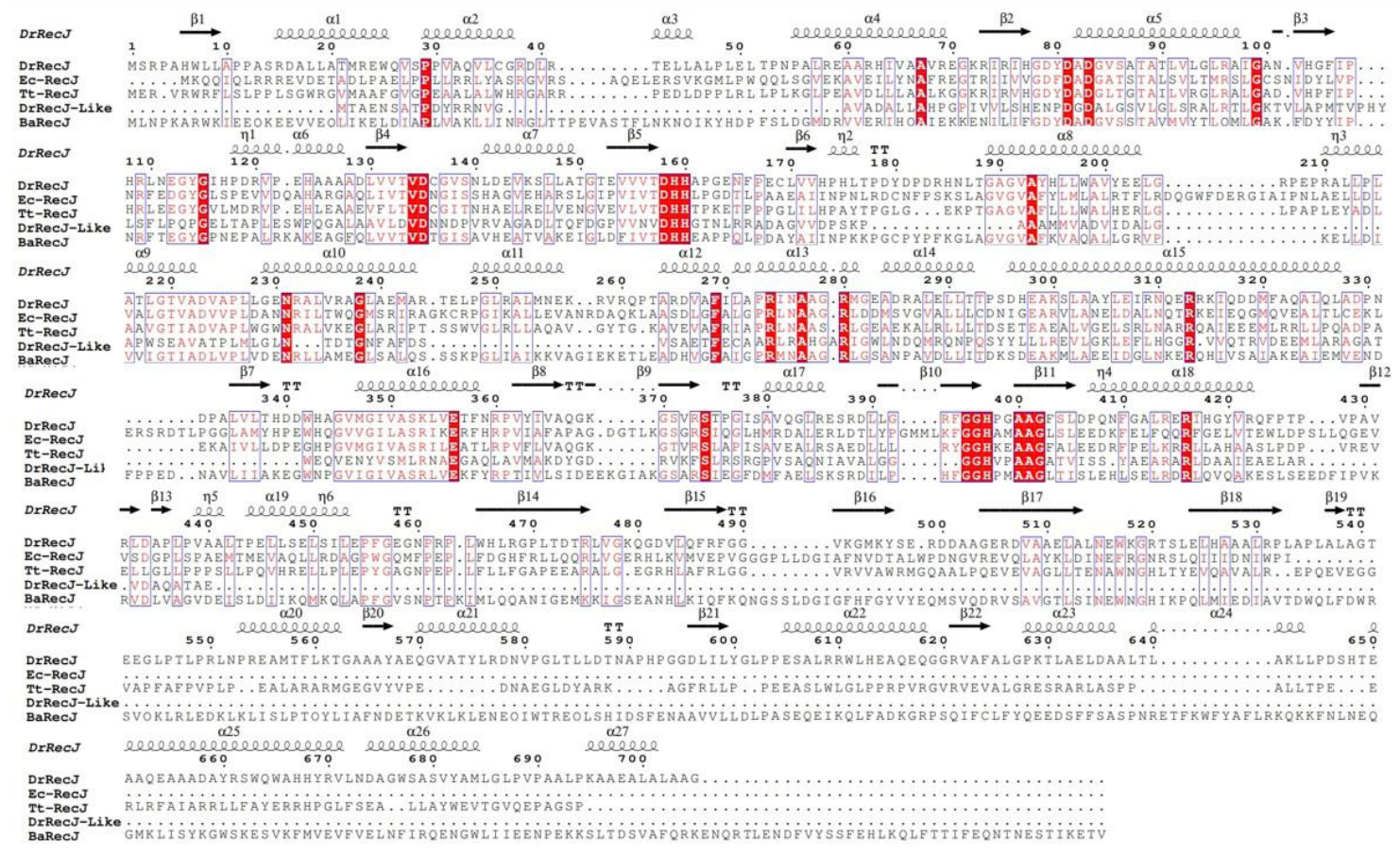

691 Supplementary Figure 1. Multiple sequence alignment of bacterial RecJs and 692 sequence analysis of mutations in BaRecJ. Sequence alignment of several 693 representative $\mathrm{RecJ} / \mathrm{DHH}$ protein superfamily members. Ba, Dr, Ec and $\mathrm{Tt}$ are 694 Bacillus. alcalophilus, Deinococcus. radiodurans, Escherichia. coli, Thermus. 695 thermophilus, respectively. Conserved domains, DHHA1 and DHH, are highlighted 696 with frames. 


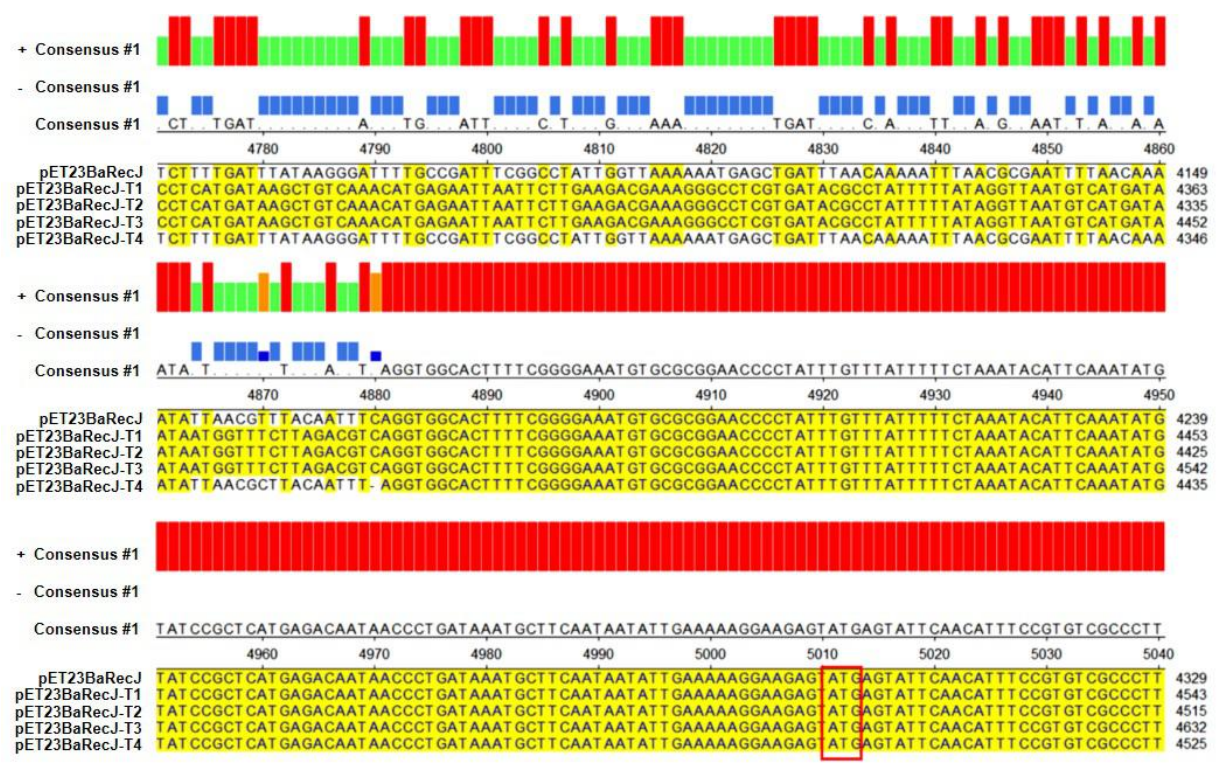

Supplementary Figure 2. Comparison of sequences between pET23BaRecJ and pET23BaRecJT1 to T4. The plasmids pET23BaRJT1 to T4 were respectively isolated from surviving transformants of $\mathrm{pET} 23 \mathrm{BaRJ}$ and sequenced. The DNA region from bases 4000 to 5100 was aligned. The ATG start codon of the antibiotic resistance gene is highlighted in a black rectangle.

(1)

8

(1)

(1)

(1)

(3)


A

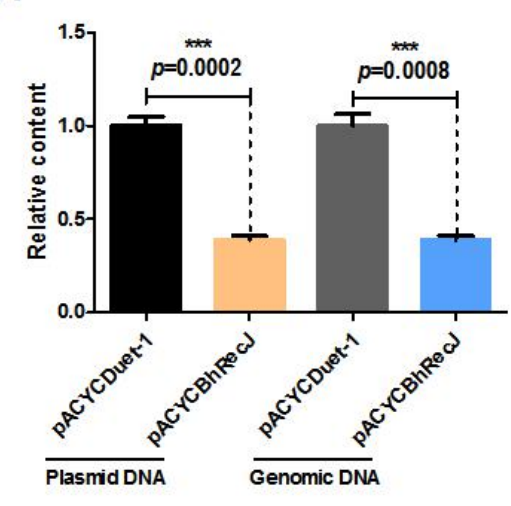

C

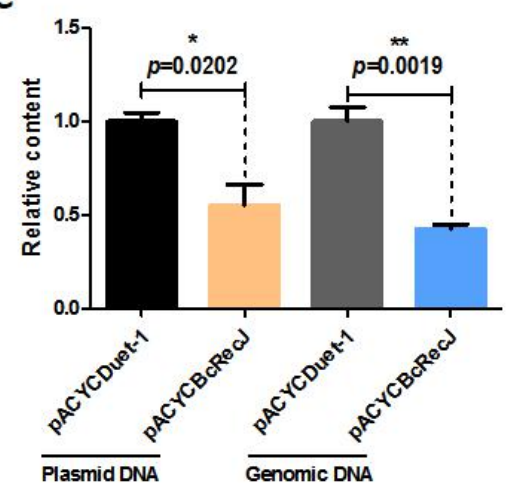

B

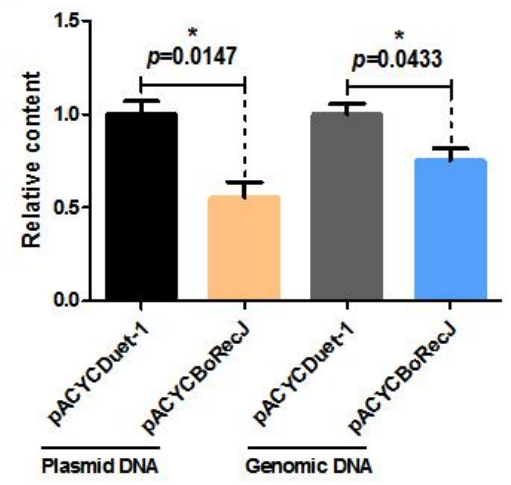

D

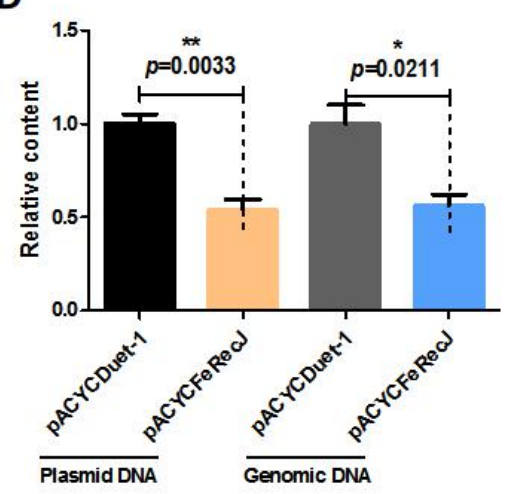

Supplementary Figure 3. Plasmid and genome content of E. coli BL21 (DE3) transformed with BaRecJ homologs. A Yield of plasmid and genomic DNA from cells transformed with pACYCBhRecJ or pACYCDuet-1. B Yield of plasmid and genomic DNA from cells transformed with pACYCBoRecJ or pACYCDuet-1. C Yield of plasmid and genomic DNA from cells transformed with pACYCBcRecJ or pACYCDuet-1. D Yield of plasmid and genomic DNA from cells transformed with pACYCFeRecJ or pACYCDuet-1. The plasmid and genomic DNAs were extracted from the same amount of biomass of transformants induced for $3 \mathrm{~h}$. All data were obtained from mean values of three independent experiments. Error bars depict standard deviations of biological triplicates. 


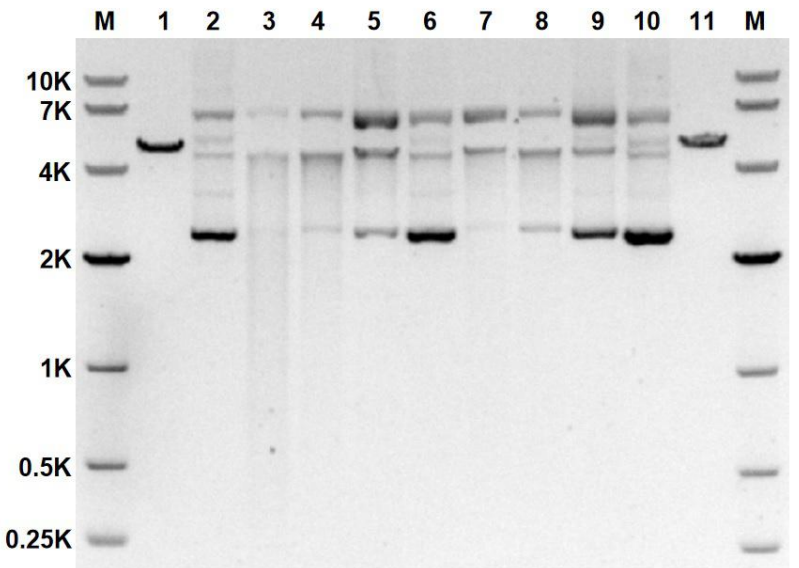

Supplementary Figure 4. The metal preference of BaRecJ. The activity of BaRecJ (500 $\mathrm{nM}$ BaRecJ, $750 \mathrm{ng}$ plasmid DNA, cleavage for $2 \mathrm{~h}$ at $37^{\circ} \mathrm{C}$ ) in the presence of 1 $\mathrm{mM} \mathrm{Mg}{ }^{2+}, \mathrm{Mn}^{2+}, \mathrm{Ca}^{2+}, \mathrm{Cu}^{2+}, \mathrm{Li}^{+}, \mathrm{Ni}^{2+}$, or $\mathrm{Co}^{2+}$ (lanes 3-9, respectively). Lane 1, pUC19-s control linearized with EcoRI; lane 2, pUC19-s plasmid control. 
Supplementary Figure 5. Time course of BaRecJ activity toward linear dsDNA (593 bp) at $37^{\circ} \mathrm{C}(500 \mathrm{nM}$ BaRecJ, $750 \mathrm{ng}$ linear dsDNA). Lanes 1-5: linear dsDNA control, and digestion for $30,60,120$, and $180 \mathrm{~min}$, respectively.

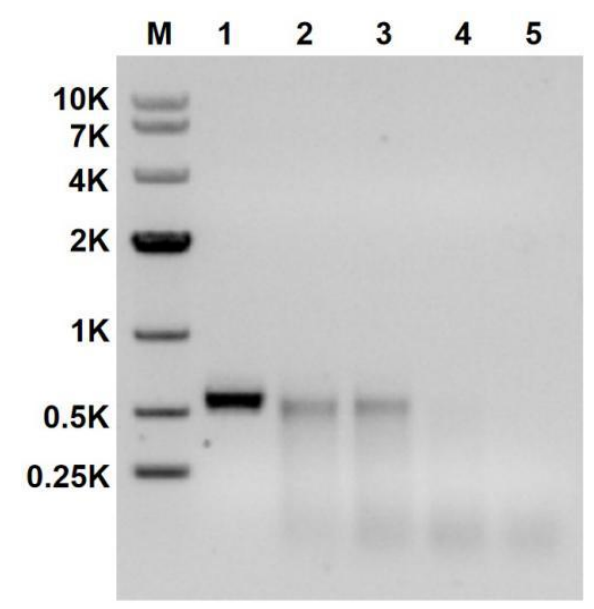




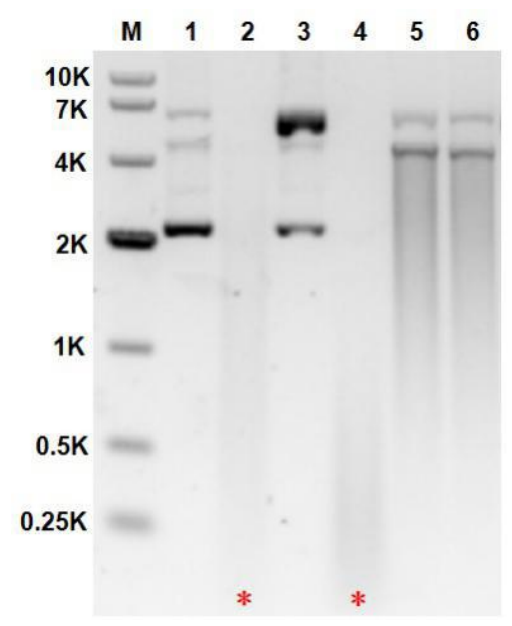

802

803

804 Supplementary Figure 6. Electrophoresis of the final plasmid degradation products

805 of wt BaRecJ and its truncations (500 nM protein, $750 \mathrm{ng}$ plasmid DNA, cleavage for

$8062 \mathrm{~h}$ at $37^{\circ} \mathrm{C}$ ). Lanes 1-6: pUC19-s control plasmid, cleavage by wt BaRecJ, and

807 cleavage by BaRecJ fragments aa 1-471, aa 471-787, aa 471-653, and aa 653-787,

808 respectively.

809

810

811

812

813

814

815

816

817

818

819

820

821

822

823

824

825

826

827 


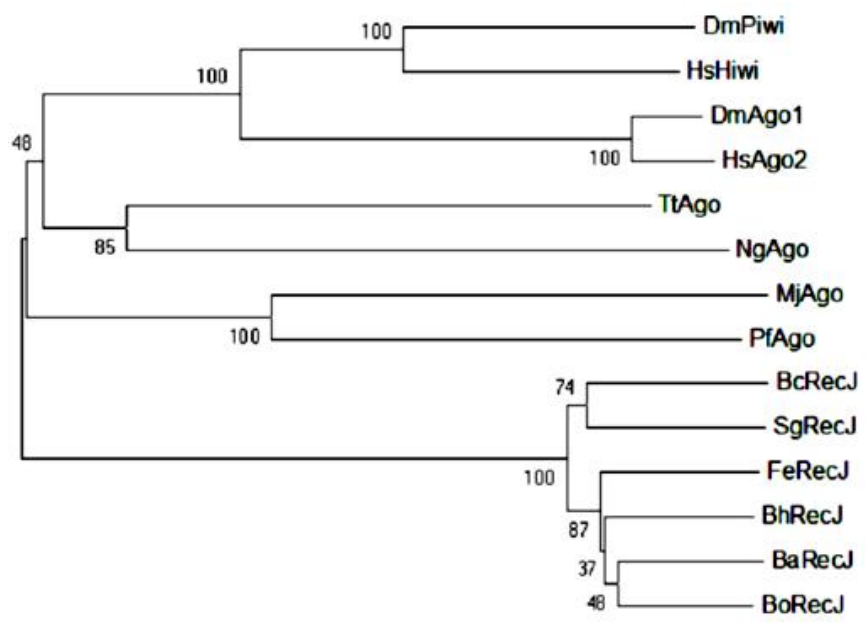

828

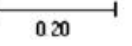

829

830 Supplementary Figure 7. Phylogenetic tree of bacterial RecJs. The bootstrap values

831 are listed at the branch points.

832

833

834

835

836

837

838

839

840

841

842 


\section{A}
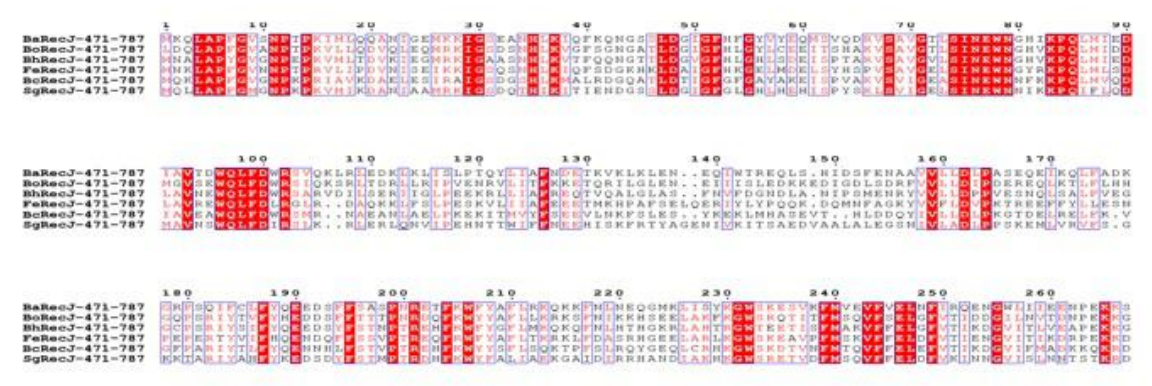

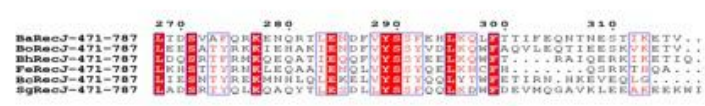

B

845 Supplementary Figure 8. Comparison of RecJ with homologous proteins. A

846 Sequence alignment of several representative RecJ protein superfamily members. Ba,

847 Bo, Bh, Fe, Bc, Sg are B. alcalophilus, B. okhensis, B. halodurans, F. enclensis, B.

848 cereus, and Sporosarcina globispora, respectively. B, C The activity of wt BaRecJ

849 and its homologous proteins in vivo. Grown to the same OD $_{600}$, diluted bacterial

850 suspensions of wt BaRecJ, cells transformed with homologous genes, and a pET28a(+)

851 vector control strain were spotted onto plates containing $0.1 \mathrm{mM}$ IPTG and cultured

852 overnight at $37^{\circ} \mathrm{C}$.
C

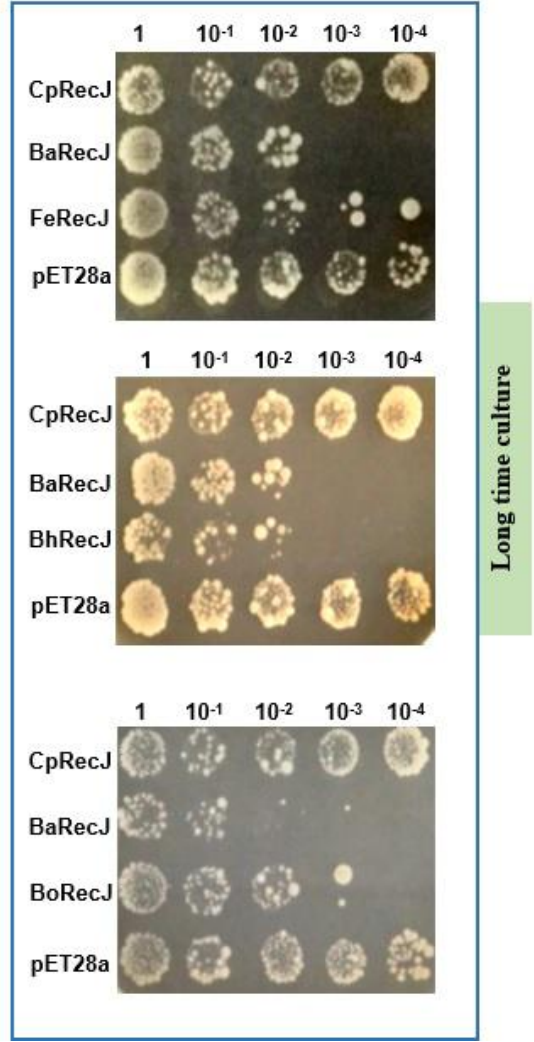


A

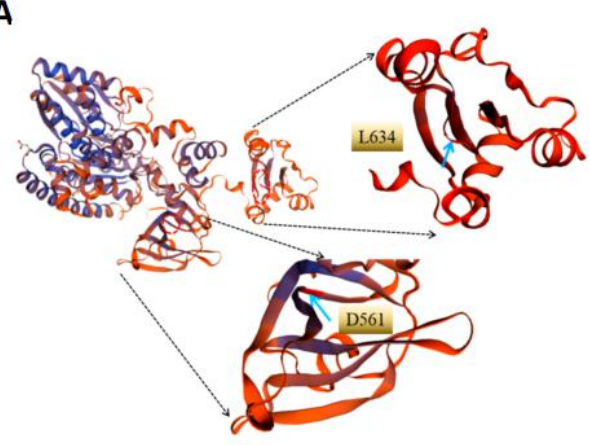

B

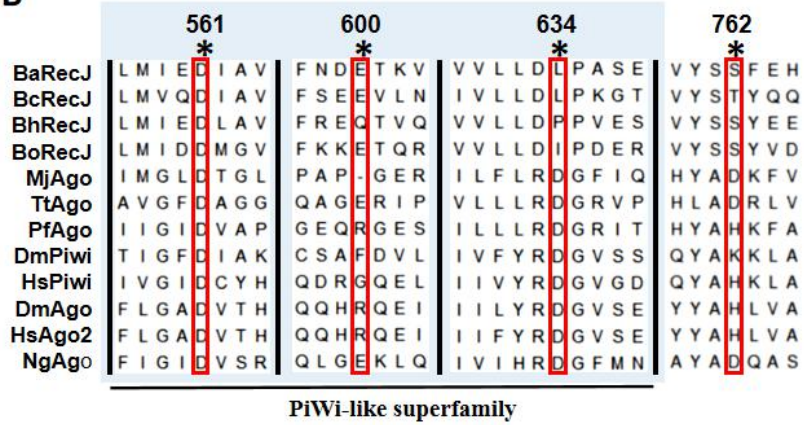

859

860

861

862

863

864

865

866

867

868

869

870

871

872

873

874

875

876

877

878

879

880

Supplementary Figure 9. Bioinformatics analysis of BaRecJ. A Prediction of 3D structure of BaRecJ through RCSB PDB website. B Multiple sequence alignment including the core motifs of BaRecJ and homologous proteins. Red boxes denote predicted active-site residues of wt BaRecJ. 
A

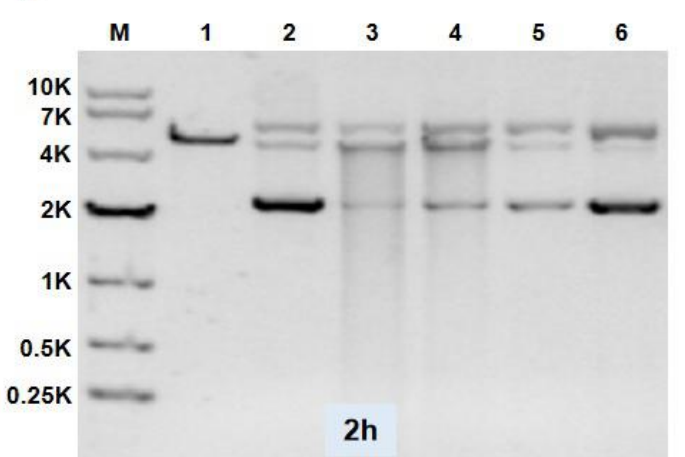

C
B

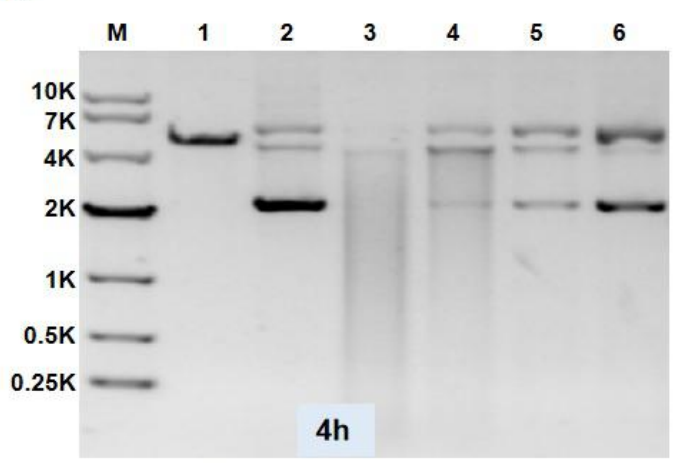

E

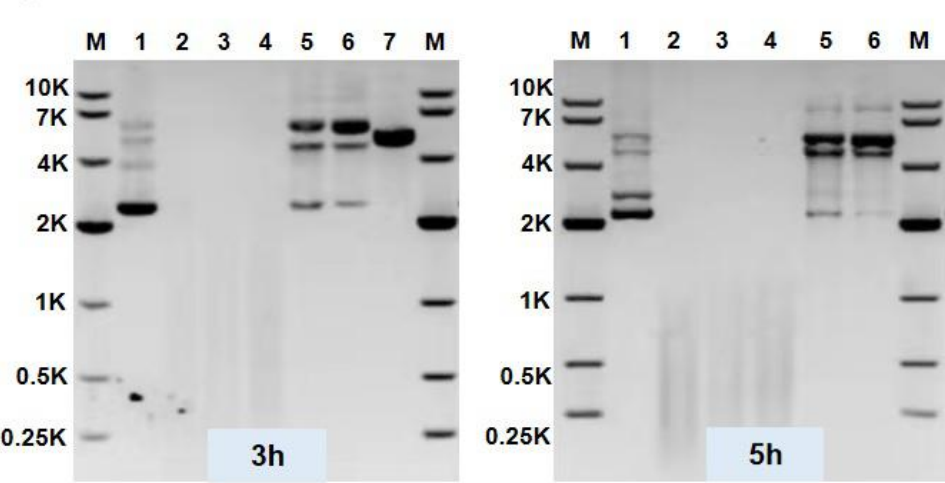

Supplementary Figure 10. Characterization of the nuclease activity of BaRecJ reloaded with different guides. A, B and $\mathbf{C}$ Different guides (25 nucleotides [nt]) were used for DNA-guided cleavage reactions; $800 \mathrm{nM}$ BaRecJ was reloaded with $1.2 \mu \mathrm{M}$ ssDNA guide, mixed with $40 \mathrm{nM}$ target plasmid DNA and incubated at $37^{\circ} \mathrm{C}$ for 1 (A), 3 (B), or 5 h (C). Lanes 1-7: pUC19-s control plasmid, cleavage by wt BaRecJ, effect of BaRecJ reloaded with 5'-P ssDNA, effect of BaRecJ reloaded with 5'-OH ssDNA, effect of BaRecJ reloaded with S-modified ssDNA, effect of BaRecJ reloaded with S-modified 5'-P ssDNA, and pUC19-s linearized with EcoRI. D, E Different guide strand lengths $(15,20,25,35$ nucleotides [nt]) were used in cleavage reactions $(800$ $\mathrm{nM}$ BaRecJ, $1.2 \mu \mathrm{M}$ S-modified ssDNA guide, $40 \mathrm{nM}$ target plasmid DNA). The reactions were incubated at $37^{\circ} \mathrm{C}$ for 2 (D) or $4 \mathrm{~h}(\mathbf{E})$. Lanes 1-6: pUC19-s linearized with EcoRI, pUC19-s control plasmid, pUC19-s cleaved by wt BaRecJ and 15-nt S-modified ssDNA guide, pUC19-s cleaved by wt BaRecJ and 20-nt S-modified ssDNA guide, pUC19-s cleaved by wt BaRecJ and 25-nt S-modified ssDNA guide, pUC19-s cleaved by wt BaRecJ and 35-nt S-modified ssDNA guide, respectively. 


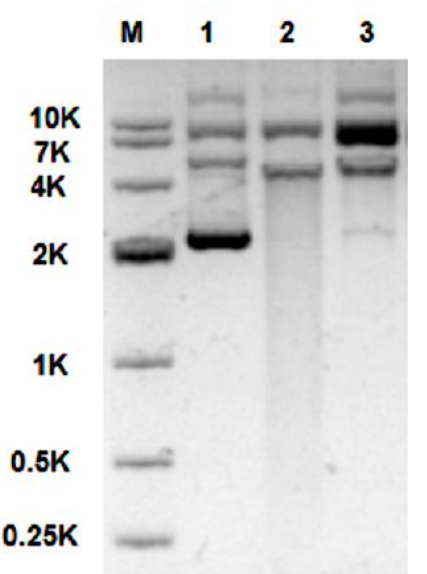

902

Supplementary Figure 11. Characterization of the nuclease activity of BaRecJ mutant was reloaded with $1 \mu \mathrm{M}$ ssDNA guide, mixed with $25 \mathrm{nM}$ target plasmid DNA and incubated at $37^{\circ} \mathrm{C}$ for $15 \mathrm{~min}$. Lanes 1-3: pUC19-s control plasmid, pUC19-s cleaved by BaRecJ L634A mutant, pUC19-s cleaved by reloaded BaRecJ L634A

910 mutant. 
Supplementary Table 1 Primers, plasmids used in this experiment.

\begin{tabular}{|c|c|c|c|c|c|}
\hline Plasmid & Oligos & Sequence(5'-3') & Template & Backbone & $\begin{array}{c}\text { Restric } \\
\text { tion } \\
\text { sites }\end{array}$ \\
\hline \multirow{4}{*}{$\mathrm{pBaRecJ}$} & BaRecJ-f1 & ATAAACCGTGGAGCGAGACC & \multirow{4}{*}{$\begin{array}{c}\text { Genomic DNA of } \\
\text { Bacillusalc alophilus } \\
\text { (ATCC } 27647 \text { and } \\
\text { CGMCC 1.3604) }\end{array}$} & \multirow{4}{*}{ pMD18-T } & \multirow{4}{*}{ I } \\
\hline & BaRecJ-r1 & CCACCAGTTGCCAATAAGTC & & & \\
\hline & BaRecJ-f2 & ATGTTGAATCCAAAGGCAAG & & & \\
\hline & BaRecJ-r2 & TTATACCGTCTCCTTGATTG & & & \\
\hline \multirow{2}{*}{ pET23BaRecJ } & 23BaRecJ-f & $\begin{array}{c}\text { CTTTAAGAAGGAGATATACATATG } \\
\text { TTGAATCCAAAGGCAA }\end{array}$ & \multirow{2}{*}{$\mathrm{pBaRecJ}$} & \multirow{2}{*}{ pET-23b(+) } & NdeI \\
\hline & 23BaRecJ-r & $\begin{array}{c}\text { TGGTGGTGGTGGTGCTCGAGTTAT } \\
\text { ACCGTCTCCTTGATTG }\end{array}$ & & & XhoI \\
\hline \multirow{2}{*}{$\begin{array}{c}\text { pACYCBaRec } \\
\mathrm{J}\end{array}$} & $\begin{array}{c}\text { ACYCBaRe } \\
\text { cJ-f }\end{array}$ & $\begin{array}{c}\text { AGTATAAGAAGGAGATATACAAT } \\
\text { GTTGAATCCAAAGGCAA }\end{array}$ & \multirow{2}{*}{$\mathrm{pBaRecJ}$} & \multirow{2}{*}{$\begin{array}{c}\text { pACYCDue } \\
\mathrm{t}-1\end{array}$} & NdeI \\
\hline & $\begin{array}{c}\mathrm{ACYCBaRe} \\
\mathrm{cJ}-\mathrm{r}\end{array}$ & $\begin{array}{c}\text { TTTACCAGACTCGAGGGTACTTAT } \\
\text { ACCGTCTCCTTGATTG }\end{array}$ & & & KpnI \\
\hline \multirow{2}{*}{ pET28BaRecJ } & 28BaRecJ-f & $\begin{array}{c}\text { CTTTAAGAAGGAGATATACCATGT } \\
\text { TGAATCCAAAGGCAAG }\end{array}$ & \multirow{2}{*}{$\mathrm{pBaRecJ}$} & \multirow{2}{*}{ pET-28a $(+)$} & NcoI \\
\hline & 28BaRecJ-r & $\begin{array}{c}\text { TGGTGGTGGTGGTGCTCGAGTACC } \\
\text { GTCTCCTTGATTGTAC }\end{array}$ & & & XhoI \\
\hline
\end{tabular}


Supplementary Table 2 Primers used for plasmid sequencing

\begin{tabular}{|c|c|c|}
\hline $\begin{array}{l}\text { Primer } \\
\text { name }\end{array}$ & Primer sequence $\left(5^{\prime}-3{ }^{\prime}\right)$ & Assay \\
\hline $1 \mathrm{~F}$ & TTACAATTTCAGGTGGCACTTTTC & $\begin{array}{c}\text { Sequencing for } \\
\text { pET23BaRecJT1-T4 }\end{array}$ \\
\hline $1 \mathrm{R}$ & GGAATAAGGGCGACACGGAAATG & $\begin{array}{c}\text { Sequencing for } \\
\text { pET23BaRecJT1-T4 }\end{array}$ \\
\hline $2 \mathrm{~F}$ & TGAATGAAGCCATACCAAACGACGAG & $\begin{array}{c}\text { Sequencing for } \\
\text { pET23BaRecJT1-T4 }\end{array}$ \\
\hline $3 \mathrm{~F}$ & TCTGCTAATCCTGTTACCAGT & $\begin{array}{c}\text { Sequencing for } \\
\text { pET23BaRecJT1-T4 }\end{array}$ \\
\hline $4 \mathrm{~F}$ & GACACCCGCCAACACCCGCTGACGC & $\begin{array}{c}\text { Sequencing for } \\
\text { pET23BaRecJT1-T4 }\end{array}$ \\
\hline B04 & CTCGTGATACGCCTATTTTTATAGG & $\begin{array}{c}\text { Sequencing for } \\
\text { pET23BaRecJT1-T3 }\end{array}$ \\
\hline D08 & ACCCATGGCAACATTAGCCCACCGT & $\begin{array}{c}\text { Sequencing for } \\
\text { pET23BaRecJT1 }\end{array}$ \\
\hline D04 & ACCGTCAGATCCTCACTCTCTTCCG & $\begin{array}{c}\text { Sequencing for } \\
\text { pET23BaRecJT1,T2 }\end{array}$ \\
\hline H07 & TGGAGGTGCATAATGCCAAGACAAA & $\begin{array}{c}\text { Sequencing for } \\
\text { pET23BaRecJT1,T3 }\end{array}$ \\
\hline H09 & CGGTAACTATCGTCTTGAGTCCAAC & $\begin{array}{c}\text { Sequencing for } \\
\text { pET23BaRecJT2,T3 }\end{array}$ \\
\hline G11 & TGTTCCCATAGTAACGCCAATAGG & $\begin{array}{c}\text { Sequencing for } \\
\text { pET23BaRecJT3 }\end{array}$ \\
\hline $\mathrm{C} 04$ & CGGAGGTGCTGCTGATGATGTAA & $\begin{array}{c}\text { Sequencing for } \\
\text { pET23BaRecJT3 }\end{array}$ \\
\hline $\mathrm{H} 05$ & TTTTAAGGGACTTGCAGGAGTAGGT & $\begin{array}{c}\text { Sequencing for } \\
\text { pET23BaRecJT4 }\end{array}$ \\
\hline $7 \mathrm{~F}$ & TGAATTAAGGGACCGTTTACAAGTGC & $\begin{array}{c}\text { Sequencing for } \\
\text { pET23BaRecJT4 }\end{array}$ \\
\hline $\mathrm{T} 7 \mathrm{~F}$ & TAATACGACTCACTATAGGG & $\begin{array}{c}\text { Sequencing for } \\
\text { pET23BaRecJT4 }\end{array}$ \\
\hline T7TER & TGCTAGTTATTGCTCAGCGG & $\begin{array}{c}\text { Sequencing for } \\
\text { pET23BaRecJT4 }\end{array}$ \\
\hline
\end{tabular}


Supplementary Table 3. Primers used for constructing BaRecJ mutation plasmids.

\begin{tabular}{|c|c|c|}
\hline Plasmids & Oligos & Sequence (5'-3') \\
\hline \multirow{2}{*}{$\begin{array}{c}\text { pET28BaRecJ- } \\
170\end{array}$} & YAK1900(1+) & ATCGTGACTGATCACgcTGAAGCCCCACCACAA \\
\hline & YAK1900(1-) & TTGTGGTGGGGCTTCAgcGTGATCAGTCACGAT \\
\hline \multirow{2}{*}{$\begin{array}{c}\text { pET28BaRecJ- } \\
169\end{array}$} & YAK1901(1+) & GTGACTGATgcCCATGAAGCCCCACCACAATTG \\
\hline & YAK1901(1-) & GGCTTCATGGgcATCAGTCACGATAAAATCTAAACCG \\
\hline \multirow{2}{*}{$\begin{array}{c}\text { pET28BaRecJ- } \\
229\end{array}$} & YAK1538-2 & $\begin{array}{c}\text { CGTCTACTAAAGGAACTAAAGCGGCGATCGTTCCGATG } \\
\text { ACA }\end{array}$ \\
\hline & YAK1538-3 & TTTAGTTCCTTTAGTAGACG \\
\hline \multirow{2}{*}{$\begin{array}{c}\text { pET28BaRecJ- } \\
416\end{array}$} & YAK1902(1+) & CATTTTGGTGGTGcCCCAATGGCGGCCGGATTG \\
\hline & YAK1902(1-) & GCCATTGGGgCACCACCAAAATGAGGTAAAATATCACG \\
\hline \multirow{2}{*}{$\begin{array}{c}\text { pET28BaRecJ- } \\
561\end{array}$} & YAK1333-4 & $\begin{array}{c}\text { GCCAGTCCGTAACTGCGATAgCTTCAATCATAAGTTGA } \\
\text { GGT }\end{array}$ \\
\hline & YAK1333-5 & TATCGCAGTTACGGACTGGCAATTATTTGA \\
\hline \multirow{2}{*}{$\begin{array}{c}\text { pET28BaRecJ- } \\
600\end{array}$} & YAK2220-2 & CCTTTGTCGCATCATTGAATGCAATC \\
\hline & YAK2220-3 & $\begin{array}{c}\text { GATTGCATTCAATGATGCGACAAAGGTAAAATTAAAA } \\
\text { TTAGAG }\end{array}$ \\
\hline \multirow{2}{*}{$\begin{array}{c}\text { pET28BaRecJ- } \\
634\end{array}$} & YAK2220-4 & GTTCACTCGCCGGTGCATCTAATAAAACAACCG \\
\hline & YAK2220-5 & TAGATGCACCGGCGAGTGAACAAGAAATTAAGC \\
\hline \multirow{2}{*}{$\begin{array}{c}\text { pET28BaRecJ- } \\
762\end{array}$} & YAK2220-6 & GCTTTAAATGTTCAAATGCAGAATAGACAAAATC \\
\hline & YAK2220-7 & GATTTTGTCTATTCTGCATTTGAACATTTAAAGC \\
\hline \multirow{2}{*}{$\begin{array}{c}\text { pET28BaRecJ } \\
(1-470)\end{array}$} & YAK1307+ & gtgcegcgcggcagcCATATGTTGAATCCAAAGGCAAG \\
\hline & YAK1307- & $\begin{array}{c}\text { gtggtggtggtggtggtgCTCGAGTTATTTAATAATATCTAAAGA } \\
\text { AATCTC }\end{array}$ \\
\hline \multirow{2}{*}{$\begin{array}{c}\mathrm{pET} 28 \mathrm{BaRecJ} \\
(471-653)\end{array}$} & YAK1308+ & $\begin{array}{c}\text { gtgccgcgcggcagcCATATGAAACAACTTGCACCATTTGGAG } \\
\text { TG }\end{array}$ \\
\hline & YAK1308- & $\begin{array}{c}\text { gtggtggtggtggtgCTCGAGTTATTGACTTGGTCTTCCTTTAT } \\
\text { C }\end{array}$ \\
\hline \multirow[b]{2}{*}{$\begin{array}{c}\text { pET28BaRecJ } \\
(653-787)\end{array}$} & YAK1391+ & gtgccgcgcggcagcCATATGCAAATCTTTTGTTTATTTTATCA \\
\hline & YAK1391- & $\begin{array}{c}\text { GATCTCAGTGGTGGTGGTGGTGGTGCTCGAGTTATACC } \\
\text { GTCTCCTTGATT }\end{array}$ \\
\hline \multirow{2}{*}{$\begin{array}{c}\mathrm{pET} 28 \mathrm{BaRec} J \\
(471-787)\end{array}$} & YAK1334-1 & $\begin{array}{c}\text { gtgccgegcggcagccatATGAAACAACTTGCACCATTTGGAGT } \\
\text { G }\end{array}$ \\
\hline & YAK1333-6 & $\begin{array}{c}\text { cagtggtggtggtggtggtgCTCGAGTTATACCGTCTCCTTGATTG } \\
\text { TAC }\end{array}$ \\
\hline \multirow{2}{*}{$\begin{array}{c}\text { pET28BaRecJ } \\
(550-787)\end{array}$} & YAK0252+ & $\begin{array}{c}\text { AAGAAGGAGATATACATATGGTGCAGGCAAAAGAAAG } \\
\text { TCT }\end{array}$ \\
\hline & YAK0252- & $\begin{array}{c}\text { GTGGTGGTGGTGGTGGTGCTCGAGTTATACCGTCTCCT } \\
\text { TGATTG }\end{array}$ \\
\hline
\end{tabular}




\begin{tabular}{|c|c|c|}
\hline \multirow{2}{*}{$\begin{array}{l}\text { pET28BaRecJ } \\
\quad(1-241)\end{array}$} & YAK0260+ & gtgccgcgcggcagcCATATGTTGAATCCAAAGGCAAG \\
\hline & YAK02601 & $\begin{array}{l}\text { AGTGGTGGTGGTGGTGGTGCTCGAGTTATGCTAATAAA } \\
\text { CGATTTTCG }\end{array}$ \\
\hline \multirow{2}{*}{$\begin{array}{l}\text { pET28BaRecJ } \\
(241-471)\end{array}$} & YAK & gtgccgcgcggcagcCATATGGCAATGGAAGGGTTAAGTGC \\
\hline & YAK0262- & $\begin{array}{c}\text { AGTGGTGGTGGTGGTGGTGCTCGAGTTATTGTTTAATA } \\
\text { ATATCTAAAG }\end{array}$ \\
\hline
\end{tabular}

961

962

963

964

965

966

967

968

969

970

971

972

973

974

975

976

977

978

979

980

981

982

983

984

985

986

987

988

989

990

991

992

993

994

995

996

997 
Supplementary Table 4. Oligonucleotides used for characterizing the nuclease activity.

\begin{tabular}{|c|c|c|}
\hline Names & Sequences (5'-3') & Comments \\
\hline DD295 & TCCGATAGCCAGATATCTTGACA* & $\begin{array}{c}\text { Fluorescent 5'-OH ssDNA } \\
\text { strand }\end{array}$ \\
\hline DD298 & pTCCGATAGCCAGATATCTTGACA* & $\begin{array}{c}\text { Fluorescent 5'-P ssDNA } \\
\text { strand }\end{array}$ \\
\hline DD406 & TsGsTsCAAGATATCTGGCTATCsGsGsA & $\begin{array}{c}\text { Complementary to DD295 } \\
\text { and DD298 }\end{array}$ \\
\hline
\end{tabular}

${ }^{a}$ Asterisks denote the fluorescein (6-FAM) group at the 3'-end. Letters s and p denote phosphorothioate and phosphate modifications, respectively. 
Supplementary Table 5. Oligos used for characterizing endonuclease activity of BaRecJ.

\begin{tabular}{|c|c|c|c|}
\hline Oligos & Sequence( $\left(5^{\prime}-3^{\prime}\right)$ & Length (nt) & Modifications \\
\hline G15S-F & $\begin{array}{c}\mathrm{T}^{*} \mathrm{~A} * \mathrm{~T} * \mathrm{~T}^{*} \mathrm{~T} * \mathrm{C}^{*} \mathrm{G}^{*} \mathrm{~T}^{*} \mathrm{~T}^{*} \mathrm{C}^{*} \mathrm{~A} * \mathrm{~T}^{*} \\
\mathrm{C}^{*} \mathrm{C} * \mathrm{~A}\end{array}$ & 15 & Phosphorothioate \\
\hline G20S-F & $\begin{array}{c}\mathrm{C}^{*} \mathrm{~T}^{*} \mathrm{G}^{*} \mathrm{~T}^{*} \mathrm{C}^{*} \mathrm{~T}^{*} \mathrm{~A} * \mathrm{~T}^{*} \mathrm{~T}^{*} \mathrm{~T}^{*} \mathrm{C}^{*} \mathrm{G}^{*} \\
\mathrm{~T}^{*} \mathrm{~T}^{*} \mathrm{C}^{*} \mathrm{~A}^{*} \mathrm{~T}^{*} \mathrm{C}^{*} \mathrm{C}^{*} \mathrm{~A}\end{array}$ & 20 & Phosphorothioate \\
\hline G25S-F & 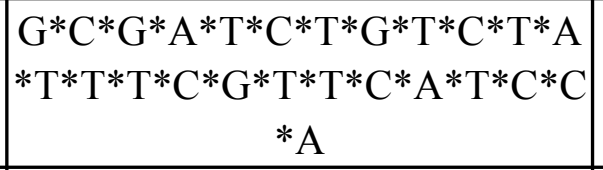 & 25 & Phosphorothioate \\
\hline G25-F & $\begin{array}{c}\text { GCGATCTGTCTATTTCGTTCA } \\
\text { TCCA }\end{array}$ & 25 & / \\
\hline G25P-F & $\begin{array}{c}\text { GCGATCTGTCTATTTCGTTCA } \\
\text { TCCA }\end{array}$ & 25 & 5'-phosphorylate \\
\hline G25PS-F & 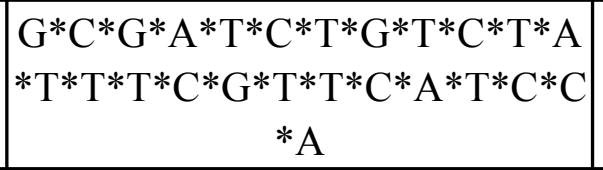 & 25 & $\begin{array}{l}\text { Phosphorothioate } \\
\text { and } \\
\text { 5'-phosphorylate }\end{array}$ \\
\hline G35S-F & 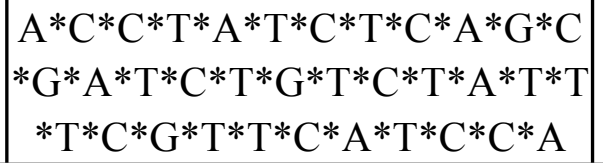 & 35 & Phosphorothioate \\
\hline
\end{tabular}

